\title{
Synergistic Effect of Curcuma longa Extract in Combination with Phyllanthus niruri Extract in Regulating Annexin A2, Epidermal Growth Factor Receptor, Matrix Metalloproteinases, and Pyruvate Kinase M1/2 Signaling Pathway on Breast Cancer Stem Cell
}

\author{
Dedy Hermansyah ${ }^{1}$, Agung Putra ${ }^{2,3,4 *}$, Delfitri Munir ${ }^{5}$, Aznan Lelo ${ }^{6}$, Nur Dina Amalina ${ }^{2,7}$, Iffan Alif ${ }^{2}$ \\ ${ }^{1}$ Department of Surgery, Faculty of Medicine, Universitas Sumatera Utara, Medan, North Sumatra, Indonesia; ${ }^{2}$ Stem Cell and \\ Cancer Research, Faculty of Medical, Sultan Agung Islamic University, Semarang, Central Java, Indonesia; ${ }^{3}$ Department of \\ Postgraduate Biomedical Science, Faculty of Medical, Sultan Agung Islamic University, Semarang, Central Java, Indonesia; \\ ${ }^{4}$ Department of Pathological Anatomy, Medical Faculty, Sultan Agung Islamic University, Semarang, Central Java, Indonesia; \\ ${ }^{5}$ Pusat Unggulan IPTEK Tissue Engineering, Faculty of Medicine, Universitas Sumatera Utara, Medan, North Sumatra, \\ Indonesia; ${ }^{6}$ Department of Pharmacology, Faculty of Medicine, Universitas Sumatera Utara, Medan, North Sumatra, Indonesia; \\ ${ }^{7}$ Pharmacy Study Program, Faculty of Mathematics and Natural Sciences, Universitas Negeri Semarang, Semarang, Indonesia
}

Edited by: Ksenija Bogoeva-Kostovska Citation: Hermansyah D, Putra A, Munir D, Lelo A, Amalina ND, Alif I. Synergistic Effect of Curcuma long Extract in Combination with Phyllanthus niruri Extract
in Regulating Annexin A2, Epidermal Growth Factor intor, Matrix Metalloproteinases, and Pyruvate Kictor M1/2 Signaling Pathway on Breast Cancer Stem Cell. M1/2 Signaling Pathway on Breast Cancer Stem Cell.
Open Access Maced J Med Sci. 2021 May 09; 9(A):271-285. https://doi.org/10.3889/oamjms.2021.594 Keywords: Curcuma longa; Phyllanthus niruri, Bioinformatics; In vitro; Metastatic; Stemness; Molecula targeted therapy *Correspondence: Agung Putra, Kaligawe Raya Km. 4 Semarang, Central Java, 50112, Indonesia. E-mail dr.agungptr@gmail.com Revised: $15-\mathrm{Apr}-2021$ Accepted: 29 -Apr-2021 Copyright: ๑ 2021 Dedy Hermansyah, Agung Putra, Delfitri Munir, Aznan Lelo, Nur Dina Amalina, Iffan Alif Funding: This research did not receive any financia

Competing Interests: The authors have declared that no competing interests exis Open Access: This is an open-access article distribute under the terms of the Creative Commons Attribution-

\begin{abstract}
AIM: This study aimed to investigate the synergistic effects of the combination between Curcuma longa extract (CL) and Phyllanthus niruri extract (PN) in inhibiting optimally the MDA-MB-231 breast cancer stem cells (BCSCs) growth and metastatic by exploring the target and molecular mechanism using integrative bioinformatics approaches and in vitro.

METHODS: CL and PN extracts were prepared by maceration method using ethanol $70 \%$. The antiproliferative effect of CL and PN single and combination treatment was examined by 3-[4,5-dimethyl-2-thiazolyl]-2,5-diphenyl-2 $\mathrm{H}$ tetrazolium bromide assay. The bioinformatic approach was performed to identify molecular targets, key proteins, and molecular mechanism of curcumin and phyllanthin as CL and PN secondary metabolite, respectively, targeted at stemness and migration pathway of BCSCs.

RESULTS: The in vitro study showed that $\mathrm{CL}$ and $\mathrm{PN}$ possess cytotoxic activity in time- and dose-dependent manner The combination of $\mathrm{CL}$ and $\mathrm{PN}$ has a synergistic effect by modulating the sensitivity of cells. Using a bioinformatics approach, the annexin A2 (ANXA2), epidermal growth factor receptor (EGFR), matrix metalloproteinases (MMPs), and pyruvate kinase M1/2 (PKM) as potential targets of curcumin and phyllanthin correlated with metastatic inhibition of BC. In addition, molecular docking showed that curcumin and phyllanthin performed similar or better interaction to stemness differentiation regulator pathway particularly histone deacetylase 1, EGFR, Heat Shock Protein 90 Alpha Family Class B Member 1, Hypoxia Inducible Factor 1 Subunit Alpha, and MMP9.

CONCLUSION: Combination of CL and PN has potential for the treatment of metastatic BCSCs by targeting ANXA2, EGFR, MMPs, and PKM to resolve stemness and inhibit of BCSCs.
\end{abstract}

\section{Background}

Breast cancer $(\mathrm{BC})$ is the most common cancer among women, presenting a major public issue around the world [1]. BC stem cells (BCSCs), a subpopulation of cancer cells that have tumor-initiating properties play a critical role in cancer recurrence, stemness, and metastasis [2], [3]. The highest mortality rate of $B C$ is caused by a cancer recurrence and metastatic complication [4]. The previous study reported that the activation of the epidermal growth factor receptor (EGFR) signaling induces epithelial-mesenchymal transition (EMT) correlated with aggressive metastatic features [5]. Recent studies provided evidences that annexin A2 (ANXA2) is involved in EGFR signaling.
The ANXA2 expression also may promotes the TGF- $\beta$ upregulation leading to activation of matrix metalloproteinases (MMPs). This phenomenon correlated to metastatic enhancement and stemness phenotype of BCSCs [6]. Therefore, blocking ANXA2 function lead to the inhibition of the EGFR and TGF- $\beta$ downstream pathway associated with the reduce of BCSCs stemness ability in cell progression, migration, and metastatic reduction [7]. On the other hand, the pyruvate kinase M1/2 (PKM2) overexpression, promotes metastasis of cancer cells that correlated with ANXA2 expression in vivo [8]. In recent years, increased attention has focused on ANXA2 and its role in regulating $B C$ development [9], [10].

In well-established medical treatment, the use of chemotherapy to control metastatic BC 
has been developed as a therapeutic protocol of cancer, irrespective of surgical treatments [11], [12]. Unfortunately, the chemotherapy effectiveness is limited by acquired chemoresistance. The previous study reported that overexpression of ANXA2 associated with chemoresistance evidence [13]. Therefore, developing natural chemotherapeutic agents to eliminate cancer cells without emerging drug resistances remain still a challenging project. The benefit used of plant extracts with natural multi-targeting capability in killing cancer cells and relatively safer to normal tissues is the one predominance reason to utilize the medical plant extracts including Curcuma longa $(\mathrm{CL})$ and Phyllanthus niruri (PN) [14], [15], [16].

$\mathrm{CL}$ and $\mathrm{PN}$ are the common medicinal plants used in Indonesia with many biological effects including anticancer activity on various cancer cells [17], [18], [19], [20], [21]. Recent studies have shown that CL extracts might suppress cancer cell proliferation by inducing the G0/G1 cell cycle arrest and trigger cell apoptosis [22], [23], [24]. Furthermore, curcumin as one of the secondary metabolite compound of $C L$ extracts has specific-binding with ANXA2 proteins to reduce the growth and size of tumor mass [18], [25], [26]. On the other hand, several studies reported that PN extracts also possess cytotoxic effects on various cancer cells such as promyelocytic leukemia HL-60 cell lines, human oral cancer HSC and BC [20], [27]. The phytochemical studies of the PN have shown that those extracts contain a variety of components, particularly phyllanthin inhibited metastatic of lung cancer through decrease MMP9 expression [28].

Recently, the combination of two or more natural chemotherapeutic agent might achieve efficacy with lower doses and in the absence of toxicity. Therefore, using the combination $\mathrm{CL}$ and $\mathrm{PN}$ was supposed to have synergistic effects in optimally inhibiting the cancer cells growth and possibly fewer side effects. In this study, we use MDA-MB-231 cells, a highly metastatic $B C$ cell line with a high population of BCSCs. This study aimed to investigate the synergistic effects of the combination between $C L$ and $P N$ in inhibiting optimally the MDA-MB-231 BC cells growth and metastatic by exploring the target and molecular mechanism using integrative bioinformatics approaches.

\section{Materials and Methods}

\section{Plant material}

CL and PN were collected in November 2019 and February 2020, respectively, in Tawangmangu, Karanganyar Central Java, Indonesia (Latitude 740'39.3"S; Longitude $\left.111^{\circ} 08^{\prime} 09.4 " \mathrm{E}\right)$. The plant identification was verified by the biologist from the center for research and development of medicinal plants and traditional medicine (B2P2TOOT), Indonesia. For biological determination, the herbs of $\mathrm{PN}$ and rhizome of $\mathrm{CL}$ were dried with circulated at $40^{\circ} \mathrm{C}$ and renewal of air oven until completely dehydrated.

\section{Extraction procedure}

$\mathrm{CL}$ and $\mathrm{PN}$ were cleaned and air-dried to constant weight at room temperature for 3 days before being ground powder in a blender. The powder of PN $(500 \mathrm{~g})$ and $\mathrm{CL}(500 \mathrm{~g})$ was extracted individually by maceration method using ethanol for $72 \mathrm{~h}$ (three cycles) based on Tanvir et al. [29] with slight modification. Then, the solutions were filtered through Whatman no.1 filter paper and the solvent was evaporated under reduced pressure (100 psi) in a rotary vacuum evaporator (IKA $\mathrm{HB} 10$ basic) at $400 \mathrm{C}$ to result in the crude extracts. The extracts were collected and preserved at 40C for subsequent analysis.

\section{Cell culture}

MDA-MB-231 (ECACC \#92020424) was maintained in Dulbecco's Modified Eagle's Mediumhigh glucose (Gibco, USA) supplemented with $10 \%$ fetal bovine serum (Gibco, USA), $12.5 \mu \mathrm{g} / \mathrm{ml}$ Amphotericin B (Gibco, USA), $150 \mu \mathrm{g} / \mathrm{ml}$ Streptomycin, and $150 \mathrm{lU} / \mathrm{ml}$ Penicillin (Gibco, USA). Cells were cultivated at $37^{\circ} \mathrm{C}$ under $5 \% \mathrm{CO}_{2}$. Culture media were renewed every 2 to 3 days, and cells were subculture when confluent of $80-90 \%$. For assays, only cells with $>90 \%$ viability, passage number $<10$, and in the log growth phase were used according to Amalina et al. [30]

\section{Cytotoxic assay}

The cytotoxic assay was based on a 3-[4,5-dimethyl-2-thiazolyl]-2,5-diphenyl-2 Htetrazolium bromide (MTT) assay according to Mosmann [31] with slight modification. Briefly, the density of $5 \times 10^{3}$ cells/well was seeded into 96 wellplate and incubated at $37^{\circ} \mathrm{C}$ under $5 \% \quad \mathrm{CO}_{2}$ for 24 h. Subsequently, cells were treated in a triple with $\mathrm{CL}$ rhizome $(5-200 \mu \mathrm{g} / \mathrm{ml})$ and $\mathrm{PN}$ herbs $(5-200$ $\mu \mathrm{g} / \mathrm{ml}$ ) and exposed for $24 \mathrm{~h}$. Untreated cells were regarded as negative controls. After treatment, cells were treated with $0.5 \mathrm{mg} / \mathrm{mL}$ of MTT (Biovision) and incubated further for $4 \mathrm{~h}$. MTT formazan was soluble using $100 \mu \mathrm{LMSO}$ and incubate for $15 \mathrm{~min}$. After incubation, the absorbance was measured by ELISA reader (BioRad iMark $^{\mathrm{TM}}$ Microplate Reader) at $\lambda$ $595 \mathrm{~nm}$. The absorbance was transformed into a percentage of cell viability by comparing the treated group with the untreated group at a particular time course. To calculated $I C_{50}$ value, linear regression between concentration $[\mathrm{x}]$ and $\%$ cell viability [y], giving the equation $y=B x+A$. Using the linear equation of this 
graph for $y=50$ value $x$ point becomes $I C_{50}$ value, that is the concentration that prevents the cell proliferation of $50 \%$. The data of this study were carried out with three replication experiments [32].

\section{Combination activity}

The first set of combination experiment, we evaluate the effectiveness of a particular concentration of $\mathrm{CL}$ rhizome, $\mathrm{PN}$ herbs, and its combination on MDA-MB-231 cells, was determined using MTT assay as described previously. MDA-MB-231 cells $\left(5 \times 10^{3}\right)$ were seeded in 96-well microplate and incubated at $37^{\circ} \mathrm{C}$ in $5 \% \mathrm{CO}_{2}$ for $24 \mathrm{~h}$. The cells were treated with one-half $I \mathrm{IC}_{50}$, one-fourth $I \mathrm{IC}_{50}$, one-eighth $\mathrm{IC}_{50}$, and onesixteenth $\mathrm{IC}_{50}$ of $\mathrm{CL}, \mathrm{PN}$, and its combination for $24 \mathrm{~h}$. After $24 \mathrm{~h}$ of treatment, the percentage of viable cells was determined using the in vitro cytotoxicity assay method described above.

\section{Analysis of combination activity}

The combination of CL and PN was determined using isobologram analysis and represented with the combination index value. $\mathrm{Cl}$ value $<1$ indicated the synergism effect and $\mathrm{Cl}$ value $>1$ indicated antagonism. The combination index analysis was based on the principle of the median effect and calculated using the following formula. Combination index $=D_{1} /[D x]_{1}+D_{2} /$ $[D x]_{2}$, where $D_{1}$ and $[D x]_{1}$ are concentrations of $C L$ Rhizome and $\mathrm{PN}$ herbs, respectively, which inhibit cell growth to $50 \%$ of control when used alone, and $\mathrm{D}_{2}$ and $[\mathrm{Dx}]_{2}$ are concentrations of $\mathrm{CL}$ rhizome and PN herbs, respectively, which have the same effect when used in combination [33]. Combination index values based on the Chou-Talalay method, calculated using CompuSyn software, indicate the effects of drug combinations [34], [35].

\section{Data collection and processing}

Cytotoxicity and mRNA arrays data were collected from $\mathrm{NCl} 60$ direct target proteins (DTP) website. The analysis of COMPARE from the $\mathrm{NCI} 60$ cell line panel was employed using public library procedures to collect drugs compounds that have similarities with Curcumin and Phyllantin. The similarity of the pattern is expressed as a Pearson coefficient of correlation. The list of compounds and genes in this study was limited to the Pearson correlation $<-0.5$ and $>0.5$.

\section{enrichment \\ Analysis of functional and pathway}

Analysis of Gene Ontology (GO) and Kyoto encyclopedia of Genes and Genomes (KEGG) pathway enrichment were performed by the Database for Annotation Visualization and Integrated Discovery, the cutoff value was selected with $p<0.05$. In addition, pathway enrichment was also performed using Overrepresentation Enrichment Analysis (ORA) from WEB-based GEne SeT Analysis Toolkit (WebGenestalt) with FDR $<0.05$ as the cutoff value.

\section{Construction of protein-protein interaction (PPI) network}

STRING-DB v11.0 was used to construct the PPI network. Confidence scores $>0.4$ were considered to be significant. Cytoscape software was used to visualize the PPI network. 10 Genes with the highest degree of the score were evaluated using Cytohubba and selected as hub genes.

\section{Molecular docking}

Simulation of docking was conducted to predict the binding interaction of curcumin and phyllanthin on histone deacetylase 1 (HDAC1), EGFR, Heat Shock Protein 90 Alpha Family Class B Member 1 (HSP90AB1), Hypoxia Inducible Factor 1 Subunit Alpha (HIF1A), and MMP9. The protein structure was obtained from the protein data bank (PDB). Chemical structure of $\mathrm{CL}$ and $\mathrm{PN}$ was preparation using ChemDraw. The energy-minimized structure of ligand and protein interaction was simulated using AutoDock Vina 1.1.2. The interaction energy between the ligand and the receptor was calculated for the entire binding site and expressed as affinity $(\mathrm{kcal} / \mathrm{mol})$. The Pymol program self-generated schematic $2 \mathrm{D}$ representations of the interfaces of protein-ligand complexes from standard pdb file input.

\section{Data analysis}

Molecular docking results were validated by determining the RMSD value of conformation bearing the lowest docking score. The validity of the molecular docking method was represented as RMSD value $<2$. Cytotoxic potencies against several cell lines were statistically analyzed basing from the $I_{50}$ values through linear regression with $p>0.05$. Values were presented as the mean \pm SD.

\section{Results}

\section{Cytotoxic effect of single doses of CL and $P N$ in inhibiting MDA-MB-231 cells proliferation}

The cytotoxic activities of $C L$ and $P N$ individually and in combination against MDA-MB-231 BC cells were determine used MTT assay in various concentration. 
MDA-MB-231 incubates in the presence of 10-200 $\mu \mathrm{g} /$ $\mathrm{ml} \mathrm{CL}$ and $\mathrm{PN}$ individually for $24 \mathrm{~h}$. In this study, we found that $C L$ and $P N$ in single treatment significantly decreased the cell viability with degree depletion in a dose-dependent manner. A single treatment of $\mathrm{CL}$ showed the cytotoxic effect on MDA-MB-231 with $\mathrm{IC}_{50}$ value of $126 \mu \mathrm{g} / \mathrm{ml}$ for $24 \mathrm{~h}$ (Figure 1a). In addition, the $\mathrm{CL}$ also caused morphological changes under inverted microscope observation (Figure 1b). Low concentration of CL has not shown significant morphological changes, but there is clearly a reduction in cell density compared to untreated. Interestingly, in the middle and high concentration of CL induced cell shrinkage, pyknosis, and fragmentation. Cell shrinkage and pyknosis are visible through inverted microscopy during the early process of apoptosis [36]. With cell shrinkage, the size of the cells is smaller, the cytoplasm denser, and the organelles tighter. Pyknosis is the result of the condensation of chromatin and the most characteristic feature of apoptosis [37], [38]. These findings clearly indicated that $C L$ has a potential to reduce cell viability against MDA-MB-231 BC cells may be through apoptosis induction.

The same phenomenon also occurs in the presence of $P N$. The $I_{50}$ value of $P N$ with respect to MDA-MB-231 was found to be $359 \mu \mathrm{g} / \mathrm{ml}$ for $24 \mathrm{~h}$ (Figure 2a). Under the inverted microscope, only in a high concentration of $\mathrm{PN}$ shows that the morphology of detached round cells that floated medium with the bubbled membrane, wrinkled nucleolus, was obliviously observed in the MDA-MB-231 cells. Such morphological characteristics are a sign of cell death and have not been seen in the untreated cells (Figure $2 b$ ). In this regard, CL had a strong inhibitory effect more than $\mathrm{PN}$. For further exploration we observed the effects of combination CL-PN on MDA-MB-231 cell growth to increase efficacy.

\section{Synergistic effect of combination CL and $P N$ to inhibit MDA-MB-231 cells proliferation}

Cells were treated for $24 \mathrm{~h}$ with several concentrations of $\mathrm{CL}$ and $\mathrm{PN}$ for to investigated the combination effect of $C L$ and $P N$ on the viability of triple negative $B C$ (TNBC) with high population of BCSCs MDA-MB-231 cells. In CL-PN combination, the $\mathrm{IC}_{50}$ value obtained after single treatment of $\mathrm{CL}$ and PN was used to determine their concentration. The concentration used wa calculated as one-half $(65 \mu \mathrm{g} / \mathrm{ml}$; $180 \mu \mathrm{g} / \mathrm{ml})$, one-fourths $(32.5 \mu \mathrm{g} / \mathrm{ml} ; 90 \mu \mathrm{g} / \mathrm{ml})$, and one-eight $(16.25 \mu \mathrm{g} / \mathrm{ml} ; 45 \mu \mathrm{g} / \mathrm{ml})$ or one-sixteenth $(8.125 \mu \mathrm{g} / \mathrm{ml} ; 22.5 \mu \mathrm{g} / \mathrm{ml})$ of $\mathrm{CL}$ and $\mathrm{PN}$, respectively. The results indicated that all concentration of either CL (Figure 1a) or PN (Figure 2a) in single treatment inhibited cell growth by $<50 \%$.

In contrast to the single treatment of $\mathrm{CL}$ and $P N$, their combination at the four concentrations above showed significantly reduced cell viability

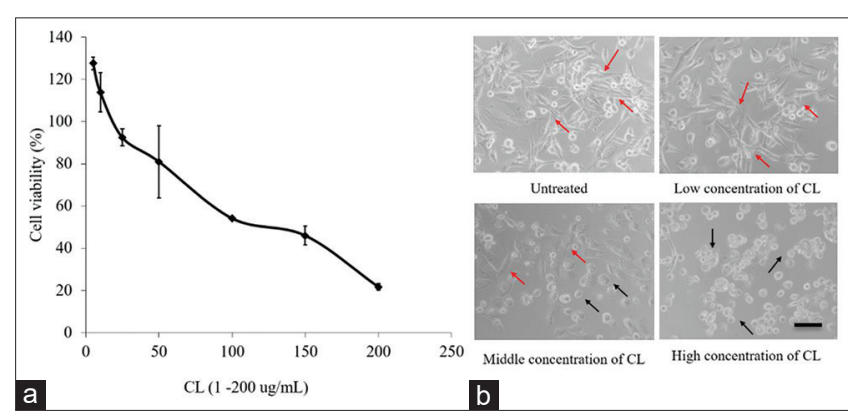

Figure 1: (a) Inhibitory effect of Curcuma longa (CL) on MDAMB231 cells proliferation. MDAMB-231 cells viability was measured after $24 h$ of $C L$. Cell viability profile expressed mean $\pm S D$ of three experiments. $I C_{50}$ obtained from a linear regression calculation of log concentration versus cell viability with $p<0.05$. (b) The effect of $C L$ on cell morphology. Visible morphological changes and population of cells in treatment of untreated, low concentration of CL $(5 \mu \mathrm{g} / \mathrm{ml})$, middle concentration of CL $(100 \mu \mathrm{g} / \mathrm{ml})$, and high concentration of CL $(200 \mu \mathrm{g} / \mathrm{ml})$. Red arrows indicated normal living cells, while black arrow indicate the morphological changes of cells. Observations of cell morphology performed using an inverted microscope with a magnification of $\times 100$. Scale bar: $100 \mu \mathrm{m}$

(Figure 3a). At all concentrations the percentage of viable cells between $50.71 \%$ and $5.93 \%$. The smallest number of viable cells was observed with maximum combination concentration of $\mathrm{CL}$ and $\mathrm{PN}$ (65 $\mu \mathrm{g} / \mathrm{ml}$ and $180 \mu \mathrm{g} / \mathrm{ml}$ ), respectively. In addition, this combination suppressed doses-dependent manner of MDA-MB-231 cells proliferation. The combination index value of CL-PN was calculated using CompuSyn, these data showed synergistic to very strong synergistic effect with $\mathrm{Cl}$ value between 0.09 and 0.36 (Table 1). Curve of concentrationeffect of CL, PN, and its combination (Figure 4a). The combination index plot showed that all of combination of treatment exhibited a synergism effect, caused the isoboles of combination CL-PN were located to the below of the curve, which indicated that CL-PN

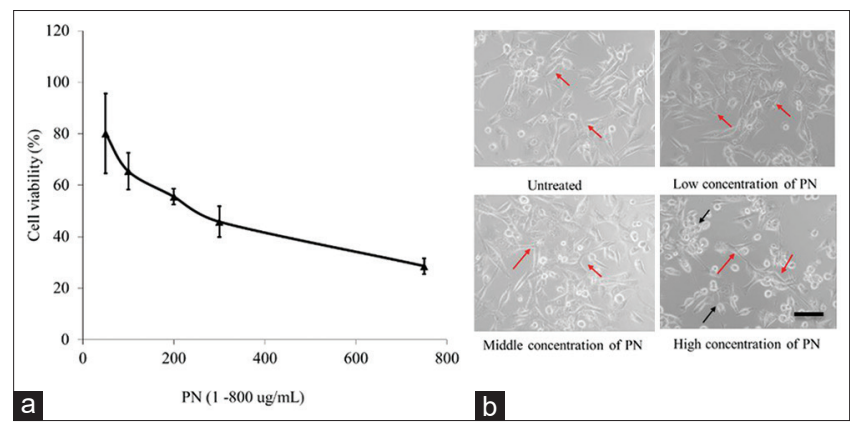

Figure 2: (a) Inhibitory effect of PN on MDAMB-231 cells proliferation. $M D A M B-231$ cells viability was measured after 24 h of PN. Cell viability profile expressed mean $\pm S D$ of three experiments. $I C_{50}$ obtained from a linear regression calculation of log concentration versus cell viability with $p<0.05$. (b) The effect of $P N$ on cell morphology. Visible morphological changes and population of cells in treatment of untreated, low concentration of Phyllanthus niruri (PN) $(5 \mu \mathrm{g} / \mathrm{ml})$, middle concentration of $P N(100 \mu \mathrm{g} / \mathrm{ml})$, and high concentration of $P N(200 \mu \mathrm{g} / \mathrm{ml})$. Red arrows indicated normal living cells, while black arrow indicate the morphological changes of cells. Observations of Cell morphology performed using an inverted microscope with a magnification of $\times 100$. Scale bar: $100 \mu \mathrm{m}$ 


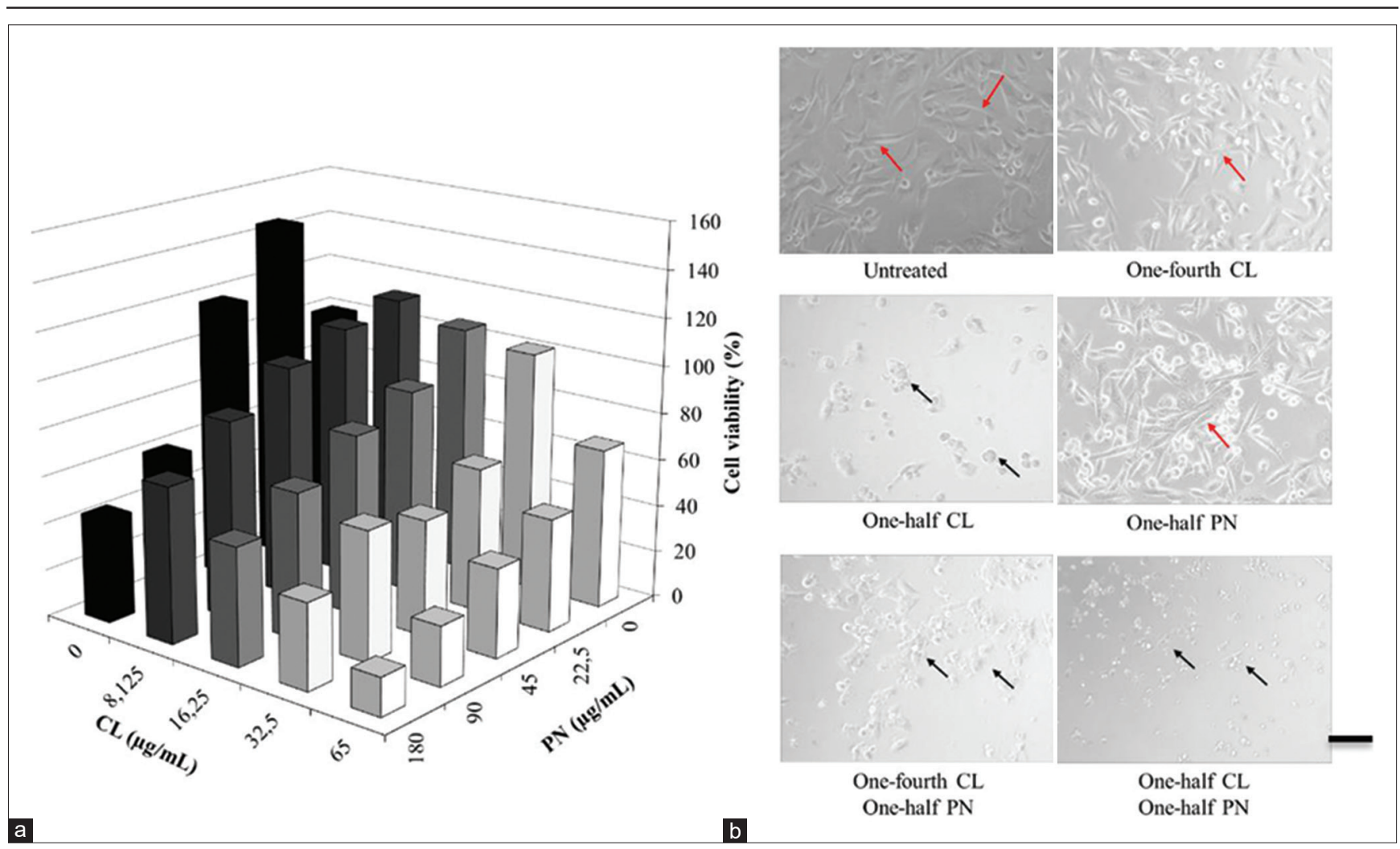

Figure 3: Combination effect of Curcuma longa-Phyllanthus niruri (CL-PN) on MDA-MB-231 cells. (a) Cells $5 \times 10^{3}$ were seeded for $24 \mathrm{~h}$ in 96-well plate, then treated with $C L, P N$ in single treatment and its combination for $24 \mathrm{~h}$. Cell viability profile expressed mean $\pm S D$ of three experiments. (b) The effect of combination CL-PN on cell morphology. Red arrows indicated normal living cells, while black arrow indicate the morphological changes of cells. Observations of Cell morphology performed using an inverted microscope with a magnification of $\times 100$. Scale bar: $100 \mu \mathrm{m}$

has synergism effect (Figure 4b). The viability cells decreased dramatically in the two observed concentration combination (one-half $\mathrm{PN}$-one-fourth $\mathrm{CL}$ and one-half $\mathrm{PN}$-one-half $\mathrm{CL}$ ), marked by unique morphological changes including improvement in the integrity of the membrane, formation of apoptotic bodies, cytoplasmic condensation, and fragmentation of DNA (Figure 3b). It was supported by previous study reported that curcumin a major compound from $\mathrm{CL}$ decreased the $\mathrm{IC}_{50}$ of MDA-MB-231 alone and in combination with paclitaxel, cisplatin, or doxorubicin. In addition, curcumin could increase by $15-$ and 5-fold drug sensitivity of MDA-MB-231 and MCF-7, respectively. BCSCs of MDA-MB-231 proliferate only to the fourth generation under combined treatment of Mitomycin C and curcumin [39]. This is an interesting phenomenon that should be explored further especially a molecular mechanism that involved in this activity, so we carried out the

Table 1: Combination index value of CL-PN calculated using CompuSyn

\begin{tabular}{|c|c|c|c|c|}
\hline \multirow[t]{2}{*}{ Concentration } & \multicolumn{4}{|c|}{$\mathrm{CL}(\mu \mathrm{g} / \mathrm{ml})$} \\
\hline & 8.125 & 16.25 & 32.5 & 65 \\
\hline \multicolumn{5}{|l|}{$\mathrm{PN}(\mu \mathrm{g} / \mathrm{ml})$} \\
\hline 22.5 & $0.29^{\star \star}$ & $0.21^{\star \star}$ & $0.09^{*}$ & $0.09^{*}$ \\
\hline 45 & $0.11^{* *}$ & $0.13^{\star *}$ & $0.10^{* *}$ & $0.13^{\star *}$ \\
\hline 90 & $0.29^{\star \star}$ & $0.35 \#$ & $0.18^{\star \star}$ & $0.24^{\star \star}$ \\
\hline 180 & $0.22^{\star \star}$ & $0.27^{\star *}$ & $0.36 \#$ & $0.18^{\star \star}$ \\
\hline
\end{tabular}

molecular mechanism exploration using integrative bioinformatics approaches.

\section{COMPARE analysis reveals the target list of $m R N A$ and the standard agent}

The molecular mechanism of $\mathrm{CL}$ and $\mathrm{PN}$ in BCSCs was explored using a bioinformatics approach. Curcumin and phyllanthin are the major compounds of $\mathrm{CL}$ and $\mathrm{PN}$ was used for subject analysis in this approach. The microarray level of mRNA expression analyzed by COMPARE revealed that 147 gene (93 gene with a positive Pearson correlation and 54 gene with a negative Pearson correlation) (Supplementary Table 1) and 200 gene (151 gene with a positive Pearson correlation and 49 gene with a negative Pearson correlation) (Supplementary Table 2) expression in the $\mathrm{NCl}-60$ cell line panel that was affected by treatment with curcumin and phyllanthin, respectively. In addition, MANEAL, HNRNPR, and RPL11 the gene regulated by curcumin and TBL3, PAG1, and ADAM22, the gene regulated by phyllanthin showed the highest Pearson correlation coefficient. A positive correlation coefficient indicates a direct correlation and implies that a higher mRNA expression enhances stemness capability of BCSCs and vice versa. Furthermore, the PubMed search using the keyword "BCSCs" resulted in 1478 gene associated with BCSCs (Supplementary Table 3). 


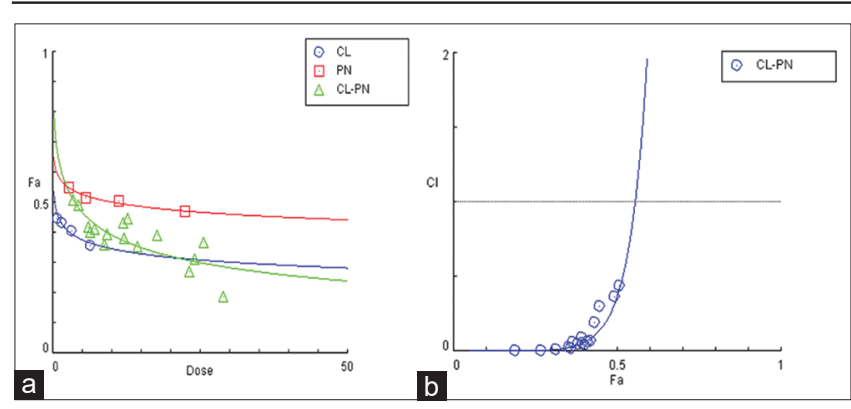

Figure 4: (a) Dose-effect curves of Curcuma longa, Phyllanthus niruri, and its combination. Dose-effect curves were generated from the CompuSyn calculation, and the value are the mean of three experiment. (b) Combination index plot among 16 combination, all off data point on the synergy side $(\mathrm{Cl}<1)$

Further, a Venny 2.1 diagram analysis (Figure 5a) of microarray data and PubMed gene list generated 1 gene that was regulated by curcumin, phyllanthin and related to BCSCs, 11 and 9 genes that were related to BCSCs and regulated by curcumin and phyllanthin individually, respectively (Supplementary Table 4). ANXA2 is a gene that was regulated by curcumin and phyllanthin. ANXA2 has the -0.52 Pearson correlation coefficient, it indicated the higher ANXA2 expression, the higher BCSCs formation. We also obtained 10 DTP of curcumin under chemical association network (STITCH) analysis, including CASP3, PTGS2, PPARG, HMOX1, AKT1, TP53, MMP9, STAT3, CCND1, and EGFR (Figure 5b). However, no one of DTP was affected by phyllanthin.

\section{GO analysis and KEGG pathway enrichment of potential curcumin and phyllanthin target genes}

GO analysis was categorized as cellular component, biological process, and molecular function. 22 gene regulated by curcumin, phyllanthin and related to BCSCs participated in the biological process of protein kinase activity, cadherin binding involved in cell-cell adhesion, cell-cell adherent junction, cell-cell adhesion, and positive regulation of protein phosphorylation. The 22 gene are located in the cell surface, membrane, plasma membrane, nucleus, and nucleoplasm. They also exert a molecular function in ATP binding, DNA binding, and transcriptional factor binding activity (Supplementary Table 4). KEGG pathway enrichment based on FDR of $<0.05$ demonstrated various pathways regulated by curcumin and phyllanthin such as cell-cell adhesion, stem cell differentiation, I-kappaB kinase/NF-kappaB signaling, metastatic, and response to oxidative stress. Pathway enrichment analyzed by WebGestalt showed stem cell differentiation regulated by curcumin and phyllanthin (Figure 6). The stem cell differentiation indicated that BCSCs loses of stemness properties and transforms into mature cells [40], [41], [42]. In addition, cell-cell adhesion significantly contributes to cancer metastatic and progression [43]. ANXA2 is involved in adhesion and also regulates the remodeling of ECM [44].

\section{PPI analysis of gene regulated by curcumin, phyllanthin and related to BCSCs}

The biological role of differential expression genes was examined using STRING data based. PPI networks were constructed of 22 genes consist of 22 nodes, 88 edges, eight average node degree, 0.0697 average local clustering coefficient, and $<4.23$ e- ${ }^{05} \mathrm{PPI}$ enrichment $p$-value (Figure 7a). The top ten genes with the highest score have been identified as HDAC1, EGFR, HSP90AB1, HIF1A, MMP9, PKM, TBK1, TNFAIP3, CHD4, and TCF3 (Figure 7b and c). These proteins correlated with stem cell differentiation and cell proliferation [45], [46].

\section{Molecular docking}

Induction of stem cell differentiation can be used as a strategic method to overcome stemness of BC cells. And also, this method could better contribute to curing patients [47]. In this study, we conducted a molecular docking simulation to predict the potential inhibitory activity of curcumin and phyllanthin in metastatic and stem cells differentiation pathway. Protein-ligand binding was visualized using Pymol (Figure 8). The ANXA2, HDAC1, EGFR, HSP90AB1, HIF1A, and MMP9 as protein target were picked from the top ten genes with the highest degree score based on their drug target uniqueness. Curcumin showed no binding interaction with HDAC1, it indicated that HDAC1 does not bind nor reacts preferentially with curcumin. However, HDAC1 slightly bind to phyllanthin with docking score value -10.4140 . The lowest docking score of curcumin and phyllanthin was found on HSP90AB1 and the highest docking score of curcumin and phyllanthin was found on MMP9 and HDAC1, respectively (Supplementary Table 5). The lower docking score suggested that highest potential of ligand binding affinity.

\section{Discussion}

BCSCs as play important role of cancer progression, cancer relapse, metastatic, and drug resistance due to of their ability to self-renew and differentiate into heterogeneous lineages of cancer cells [48]. Cancer relapse and metastatic appear to be the biggest problem for cancer patient management cause the chemotherapy only target the bulk of cancer and are unable to target BCSCs [49]. This is due to the high resistance of BCSCs, which contributes to metastasis and recurrence of cancer. 


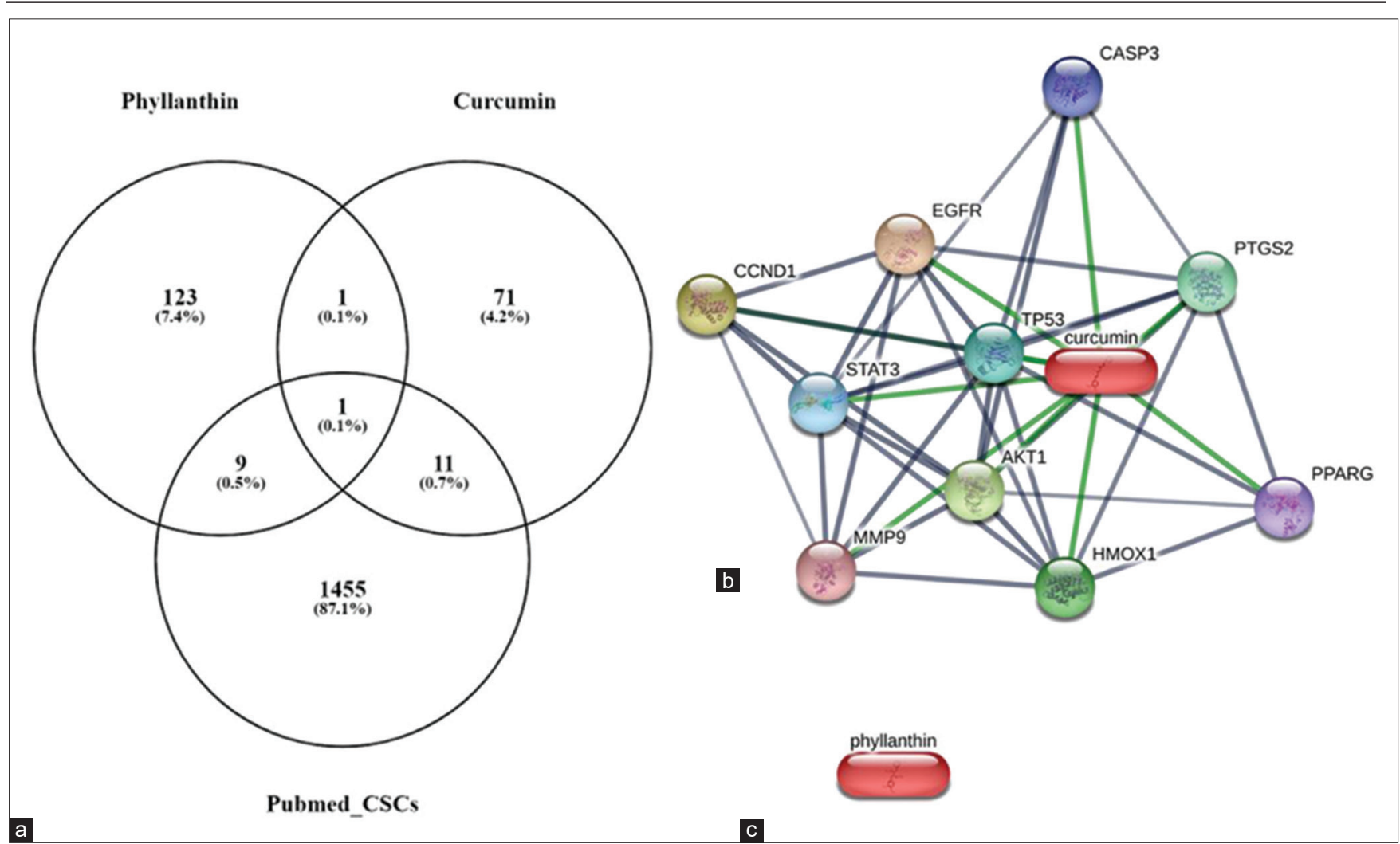

Figure 5: (a) a venn diagram of curcumin and phyllanthin potential targets against BBCSCs. (b) Curcumin interaction and is direct target proteins (DTP). (c) Phyllanthin interaction and its DTP

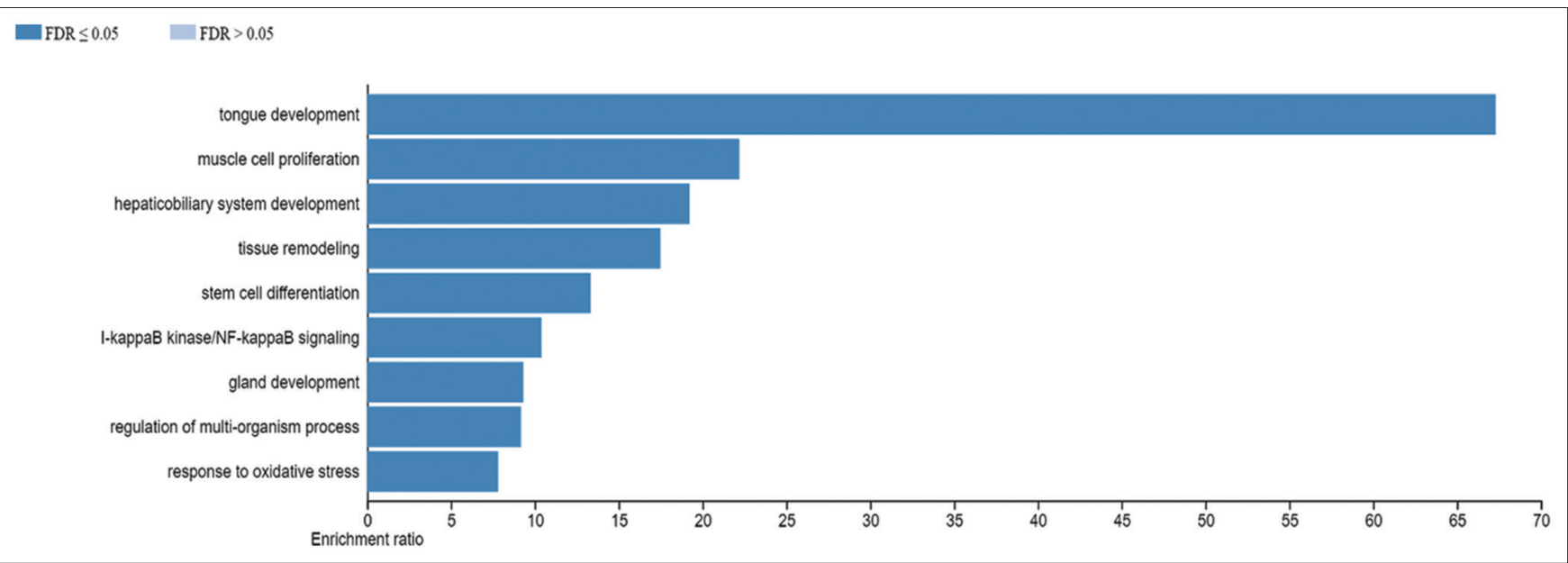

Figure 6: Kyoto encyclopedia of Genes and Genomes pathway enrichment analysis using the Overrepresentation Enrichment Analysis, WebGestalt

Until now chemotherapy remains one of the key therapeutic modalities. However, chemoresistance is limited in effectiveness. Thus, potential therapy to prevent resistance is needed such as using natural chemotherapy. The concepts of natural chemotherapy are intended to enhance efficacy and reduce the side effects of a chemical chemotherapeutic agent [50]. CL and PN are medicinal plants commonly used to treat cancer. $C L$ possess cytotoxic effect on several cancer cells [19], [51], [52]. PN has also been reported to exert many biological effects such as anticancer on various cancer cells [20], [27]. CL and PN have been shown to affect many pathways and factors associated with tumorigenesis and induced cancer cells death in large targets selectively [53]. However, in recent years the used of herbal medicine is limited as co-chemotherapy. The combination of two herbal medicines is still limited, even though natural compound that is abundant in nature is very potential to be developed further.

The present study resulted in an important finding relevant to the potential of combination natural chemotherapeutic agent, especially in triple negative $B C$ cells (TNBC) with high population of BCSCs. The cytotoxic assay resulted in this study showed that $\mathrm{CL}$ and $\mathrm{PN}$ are a very strong cytotoxic agent against 


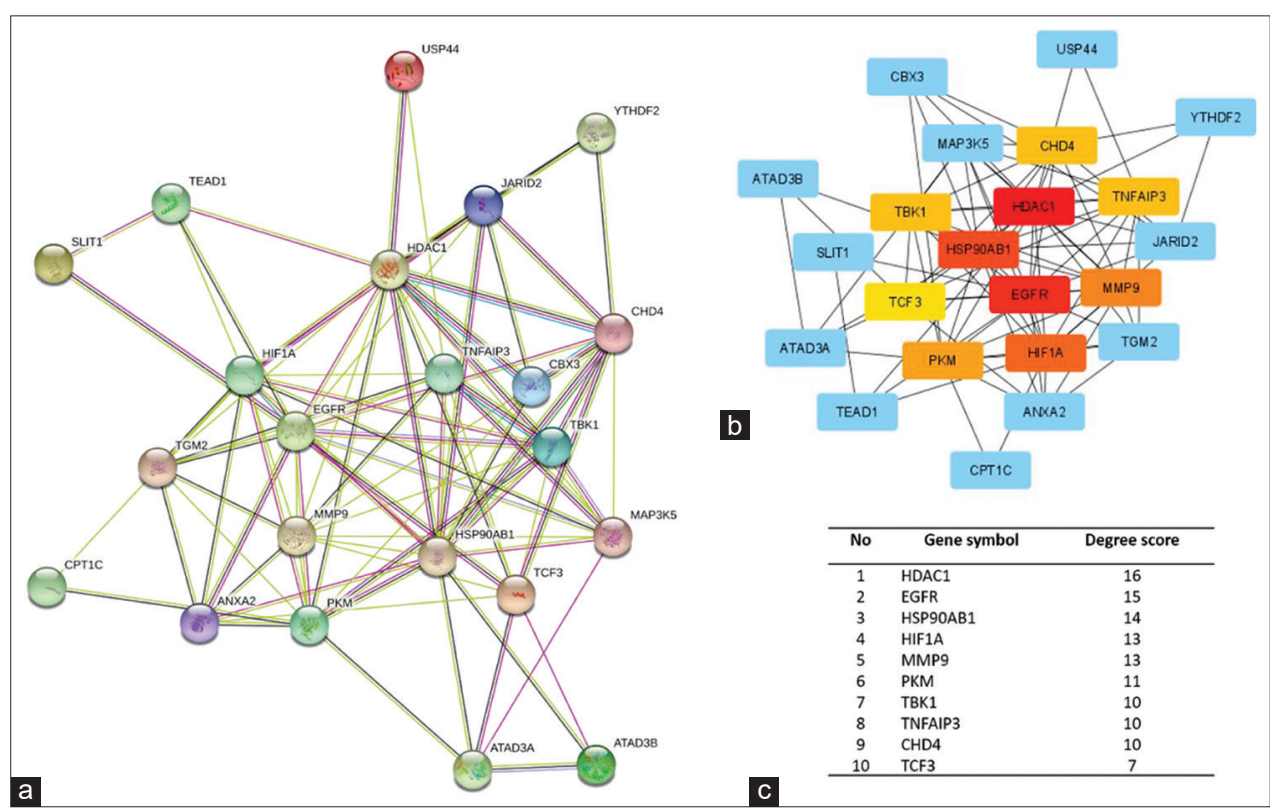

Figure 7: (a) Protein-protein interaction networks of 22 genes analyzed using STRING-DB, (b) Hub genes network analyzed using Cytohubba (red, orange and yellow box indicated the highest degree score of hub genes) and (c) Top ten hub genes based on degree score

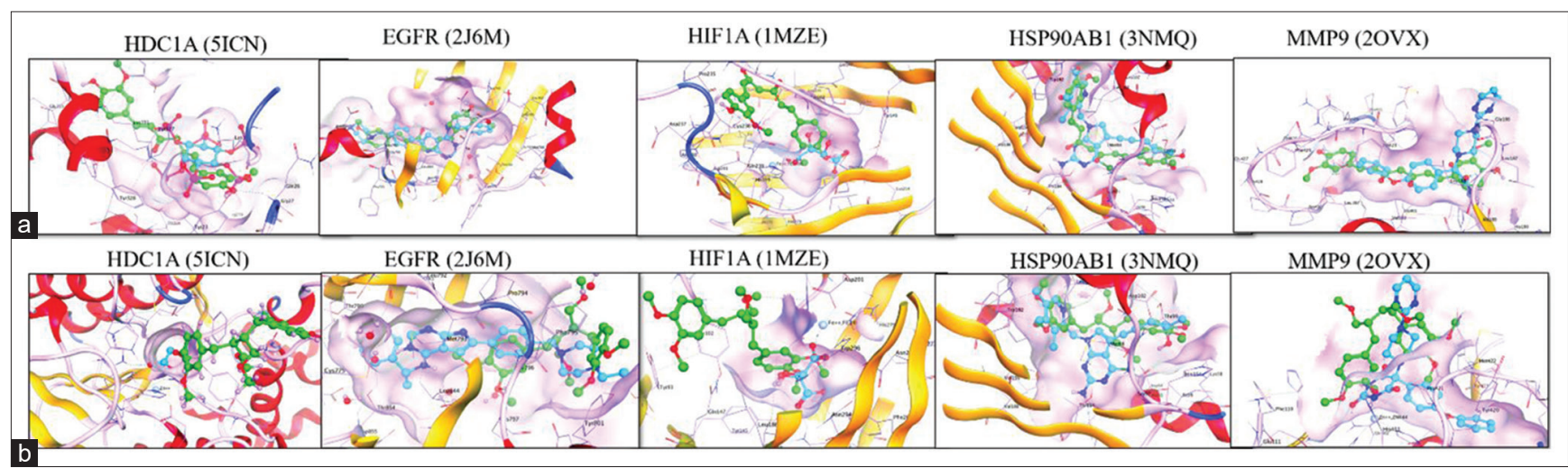

Figure 8: Molecular docking binding conformations (visualized by PyMol software) of top ten hub genes with (a) Curcumin and (b) Phyllanthin

MDA-MB-231 cells. CL and PN normally exhibited in vitro anticancer activities through a variety of mechanism in many cancer cells types, including cell cycle arrest and apoptosis induction [54]. CL also leads to an imbalance in the form of the Bcl/Bax associated apoptosis complex, which eventually causes BCSCs to lose their proliferation ability [55]. In addition, the apoptosis induction due to herbal administration through decreased expression of anti-apoptotic protein including surviving [56]. In comparison, PN was reported to be able to inhibited of MMP expression can affect the cell migration and metastasis process [57]. Based on the different mechanism of action of $C L$ and $\mathrm{PN}$, it can be predicted that these activities will be increased in combination therapy. In addition, combination therapies derived from herbal medicine significantly reduce the side effect of drug toxicity and drug resistance. Resistance condition after treatment with chemotherapy prompted the development of new compound called co-chemotherapy, which combined with chemotherapeutic agents. Co-chemotherapy usually consists of one natural compound and chemical chemotherapy, but in this study, we will combine the two potential herbal compounds without chemotherapy to get a better effect and reduce side effect.

Furthermore, the study was continued to use the combination of CL-PN to investigated combination ability to increase cytotoxic effect. The effect of combination treatment with $\mathrm{CL}$ and $\mathrm{PN}$ on proliferation depends on their single concentration, suggesting a synergistic effect. Synergy is concluded when the use of drug combinations at different doses results in greater efficacy relative to the amount of the anticancer effects produced by using the individual drugs at the same dose. Combination index values calculated using CompuSyn support this finding, in which the combination index values represent a strong or very strong synergy (combination index 0.09-0.36). Interestingly, the combination of CL-PN showed decreased dramatically of cell viability up to $20.5 \%$. These findings supported by the previous study that curcumin from $\mathrm{CL}$ in combination with Mitocymin $\mathrm{C}$ inhibits BCSCs proliferation [39]. Thus, combination of $\mathrm{CL}$ and $\mathrm{PN}$ could improve the therapeutic effect and 
reduce side effect by sensitizing $B C$ cells with high population of BCSCs and may provide a novel approach for cancer therapy. In this study, we also analysis using bioinformatics approaches to explored underlying target and molecular mechanism of the combination $\mathrm{CL}$ and PN in BCSCs.

In the bioinformatics study, we used curcumin and phyllanthin as a major compound of CL and PN, to predict tumor responsiveness to a natural product. COMPARE analysis identified 145 and 200 gene regulated by curcumin and phyllanthin, respectively. Curcumin regulated gene of RASAL2, CLIP4, and RFC3 and phyllanthin regulated gene FLJ41649, RND3, and SPATS2L with highest negative Pearson correlation coefficient. A PubMed gene data based found 1478 gene related with BCSCs. Further, a Venn diagram of COMPARE microarray data PubMed gene list produced 22 genes that were regulated by curcumin, phyllanthin and related to BCSCs. ANXA2 is only one gene that was regulated by curcumin and phyllanthin. ANXA2 involve in the cell proliferation, CSC formation and initiated EMT [58]. Indirect downregulated ANXA2 suppress protein levels of stemness-related transcription factors (Nanog, Oct4, and Sox2) through the inhibiting Akt pathway. ANXA2 also promoted the invasion and metastasis [58]. On the other hand, curcumin also exhibit a mechanism of action on several genes individually, MMP9 and EGFR are BCSCs-associated genes and can be directly affected by curcumin. The previous research reported that EGFR pathway play a critical role in regulating BCSCs [45]. Hence, curcumin and phyllanthin are multi-target and have a synergistic effect.

Analysis of KEGG pathway enrichment revealed that stem cell differentiation and NF-k $\beta$ are regulated by curcumin and phyllanthin. The previous study demonstrated that induced of cancer stem cell differentiation could be better therapy that kills cancer cells. The control of the stem cell differentiation and proliferation signaling pathway play an essential role in killing cancer cells [47]. Moreover, the PPI network reported that 12 genes had a degree score more than 10. HDAC1, EGFR, HSP90AB1, HIF1A, and MMP9 are the five genes with highest degree scores. HIF1A is a master transcriptional regulator of hypoxia condition, which induces EMT and BCSCs niche formation and also chemo and radio resistance of BCSCs. Under hypoxia, HIF1A regulate resistance and metastatic potential to BCSCs. It indicates that HIF1A is critically for survival, self-renewal, and BCSCs growth [59]. Further, the interaction of curcumin and phyllanthin on HIF1A genes in BCSCs may present breakthrough therapy for induced BCSCs differentiation to mature cells. Thus, mature cancer cells could make them easy to kill. In the other hand, activation of EGFR a member of EGFR/ErbB tyrosine kinases family also could increase tumorsphere formation, a characteristic ability of BCSCs [45]. Interestingly, curcumin and phyllanthin showed high binding affinity with EGFR based on molecular docking simulation. It indicated that the interaction between curcumin and phyllanthin to EGFR could inhibit EGFR activation pathway which impact on inhibited metastasis. The results support the previous findings that treatment with EGFR inhibitor, results in loss of tumorsphere-forming ability [60]. In addition, inhibiting EGFR components of signaling pathway resulting in the reduced survival and higher motility of BCSCs. Curcumin and phyllanthin also showed effect on direct interaction with MMP9. Previously has been reported that downregulation of MMP9 inhibited the cancer invasion. In addition, the previous study also confirms that curcumin induced downregulation of MMP9 through inhibition of I $\mathrm{kB}-\alpha$ degradation [61]. Hence, inhibition a cancer BCSCs one of marker stem cells differentiation can be used a strategic method to overcome the stemness. Another mechanism of CL-PN is influence on HSB90AB1 gene. The lowest docking score of curcumin and phyllanthin embedded into HSB90AB1 showed that CL-PN influence on cancer stem cells differentiation pathway and cell migration, invasion and metastasis. A recent study established a crucial role of HSP90AB1 in the stemness development in immunerefractory tumors: The NANOG-driven HSP90A/TCL1A/ Akt pathway is responsible for the emergence of CSClike tumor cells exhibiting an insusceptibility to immune attack, aggressiveness, and multi-modal resistance. Using selective inhibitors of HSP90AB1 such as curcumin and phyllanthin can be conductive EMT in carcinoma of different localization. Hence, inhibition of intracellular HSP90AB1 was reported to inhibit EMT via activation of HIF1A and NF-k $\beta$ [62].

\section{Conclusion}

In this study, CL and PN suggested strong synergistic effect to inhibited BC cells proliferation. Moreover, $\mathrm{CL}$ and $\mathrm{PN}$ in combination showed that induced sensitivity on $\mathrm{BC}$ cell line with a high population of BCSCs. More important, using a bioinformatics approach curcumin and phyllanthin a major compound of $C L$ and $P N$, respectively demonstrated that regulated on stem cell differentiation and metastatic pathway in overcoming stemness in BC. Molecular docking study showed the possible target of curcumin and phyllanthin against stem cell differentiation regulator pathway. Overall, combination of $C L$ and $P N$ has potential for the treatment of BCSCs and the finding of this study could be beneficial for research on accelerating and directing the screening of possible targets and identifying the molecular mechanism of curcumin and phyllanthin to resolve stemness of BCSCs. 


\section{Authors' Contributions}

$A G$ and $\mathrm{DH}$ contributed to the conception of the work. AG, DH, DM, AL, and NDA contributed to the acquisition of the work. DH and NDA contributed to the analysis and interpretation of data. AG and NDA contributed to drafting the work. AG, DNA, and DH contributed to revising the work critically. DM contributed to the revising of the manuscript. AG is responsible for giving the final approval of the manuscript.

\section{Acknowledgments}

We thank the stem cell and cancer research for their facility to support this study.

\section{References}

1. World Health Organization. Latest Global Cancer Data: Cance Burden Rises to 18.1 Million New Cases and 9.6 Million Cancer Deaths in 2018. Geneva: World Health Organization; 2018. p. 13-5. Available from: http://www.gco.iarc.fr/today/ online-analysis-pie $? \mathrm{v}=2018 \&$ mode $=$ cancer\&mode population $=$ continents \&population $=900 \&$ populations $=900 \&$ key $=$ total $\&$ sex $=2 \&$ cancer $=39 \&$ type $=0 \&$ statistic $=5 \&$ prevalence $=0 \&$ population group $=0 \&$ ages group $\% 5 \mathrm{~B} \% 5 \mathrm{D}=6 \&$ ages group $\% 5 \mathrm{~B} \% 5 \mathrm{D}=$ 13\&nb_items $=7 \&$ group.https://doi.org/10.1787/20758480 -table13. [Last accessed on $2021 \mathrm{Feb} 24]$

2. Oskarsson T, Batlle E, Massagué J. Metastatic stem cells: Sources, niches, and vital pathways. Cell Stem Cell. 2014;14(3):306-21. https://doi.org/10.1016/j.stem.2014.02.002 PMid:24607405

3. Rey I, Putra A, Lindarto D, Yusuf F. Association between CD133 expression and clinicopathological profile in colorectal cancer. Med Glas (Zenica). 2020;17(2):304-9.

PMid:32253906

4. Dillekås $\mathrm{H}$, Rogers MS, Straume O. Are $90 \%$ of deaths from cancer caused by metastases? Cancer Med. 2019;8(12):5574-6. https://doi.org/10.1002/cam4.2474

PMid:31397113

5. Barr S, Thomson S, Buck E, Russo S, Petti F, Sujka-Kwok I, et al. Bypassing cellular EGF receptor dependence through epithelial-to-mesenchymal-like transitions. Clin Exp Metastasis. 2008;25(6):685-93. https://doi.org/10.1007/s10585-007-9121-7 PMid:18236164

6. Hwang J, Hodis HN, Hsiai TK, Asatryan L, Sevanian A. Role of annexin II in estrogen-induced macrophage matrix metalloproteinase-9 activity: The modulating effect of statins. Atherosclerosis. 2006;189(1):76-82. https://doi.org/10.1016/j. atherosclerosis.2005.11.026 PMid:16386257

7. Shetty PK, Thamake SI, Biswas S, Johansson SL, Vishwanatha JK. Reciprocal regulation of annexin A2 and EGFR with her-2 in her-2 negative and herceptin-resistant breast cancer. PLoS One. 2012;7(9):e44299. https://doi.org/10.1371/ journal.pone.0044299

PMid:22957061

8. Cheng TY, Yang YC, Wang HP, Tien YW, Shun CT, Huang HY, et al Pyruvate kinase M2 promotes pancreatic ductal adenocarcinoma invasion and metastasis through phosphorylation and stabilization of PAK2 protein. Oncogene. 2018;37(13):1730-42. https://doi.org/10.1038/s41388-017-0086-y

PMid:29335522

9. Gibbs LD, Mansheim K, Maji S, Nandy R, Lewis CM, Vishwanatha JK, et al. Clinical significance of annexin A2 expression in breast cancer patients. Cancers (Basel). 2021;13(1):2. https://doi.org/10.3390/cancers13010002 PMid:33374917

10. Christensen MV, Høgdall CK, Umsen KM, Høgdall EV. Annexin A2 and cancer: Asystematic review. Int J Oncol. 2018;52(1):5-18. PMid:29115416

11. Dos Santos AF, De Almeida DRQ, Terra LF, Baptista MS, Labriola L. Photodynamic therapy in cancer treatment - an update review. J Cancer Metastasis Treat. 2019;5:25. https:// doi.org/10.20517/2394-4722.2018.83

12. Middleton JD, Stover DG, Hai T. Chemotherapy-exacerbated breast cancer metastasis: A paradox explainable by dysregulated adaptive-response. Int J Mol Sci. 2018;19(11):3333. https://doi. org/10.3390/ijms 19113333

PMid:30373101

13. Wang $\mathrm{Y}$, Chen $\mathrm{K}$, Cai $\mathrm{Y}$, Cai $\mathrm{Y}$, Yuan $\mathrm{X}$, Wang $\mathrm{L}$, et al. Annexin A2 could enhance multidrug resistance by regulating NF-KB signaling pathway in pediatric neuroblastoma. J Exp Clin Cancer Res. 2017;36(1):111. https://doi.org/10.1186/ s13046-017-0581-6

PMid:28814318

14. Kooti W, Servatyari K, Behzadifar M, Asadi-Samani M, Sadeghi $\mathrm{F}$, Nouri B, et al. Effective medicinal plant in cancer treatment, Part 2: Review study. J Evid Based Complement Altern Med. 2017;22(4):982-95. https://doi.org/10.1177/2156587217696927 PMid:28359161

15. Kuruppu AI, Paranagama P, Goonasekara CL. Medicinal plants commonly used against cancer in traditional medicine formulae in Sri Lanka. Saudi Pharm J. 2019;27(4):565-73. https://doi. org/10.1016/j.jsps.2019.02.004

PMid:31061626

16. Yin SY, Wei WC, Jian FY, Yang NS. Therapeutic applications of herbal medicines for cancer patients. Evid Based Complement Altern Med. 2013;2013:302426.

PMid:23956768

17. Huang ST, Yang RC, Yang LJ, Lee PN, Pang JH. Phyllanthus urinaria triggers the apoptosis and $\mathrm{Bcl}-2$ down-regulation in Lewis lung carcinoma cells. Life Sci. 2003;72(15):1705-16. https://doi.org/10.1016/s0024-3205(03)00016-x PMid:12559392

18. Larasati YA, Yoneda-Kato N, Nakamae I, Yokoyama $T$, Meiyanto E, Kato JY. Curcumin targets multiple enzymes involved in the ROS metabolic pathway to suppress tumor cell growth. Sci Rep. 2018;8(1):2039. https://doi.org/10.1038/ s41598-018-20179-6 PMid:29391517

19. Perrone D, Ardito F, Giannatempo G, Dioguardi M, Troiano G Lo Russo L, et al. Biological and therapeutic activities, and anticancer properties of curcumin. Exp Ther Med. 2015;10(5):1615-23. https://doi.org/10.3892/etm.2015.2749 PMid:26640527

20. Tang YQ, Jaganath IB, Sekaran SD. Phyllanthus spp. induces selective growth inhibition of $\mathrm{PC}-3$ and mewo human cancer cells through modulation of cell cycle and induction of apoptosis. 
PLoS One. 2010;5(9):e12644. https://doi.org/10.1371/journal. pone.0012644

PMid:20838625

21. Yew HC, Nordin FJ, Thiam TT, Azimahtol HL, Abdullah NR, Ismail Z. Antiproliferative property and apoptotic effect of xanthorrhizol on MDA-MB-231 breast cancer cells. Anticancer Res. 2008;28(6A):3677-89.

PMid:19189649

22. Carneiro ML, Porfírio EP, Otake AH, Chammas R, Báo SN Guillo LA. Morphological alterations and G0/G1 cell cycle arrest induced by curcumin in human SK-MEL-37 melanoma cells. Braz Arch Biol Technol. 2010;53(2):343-52. https://doi. org/10.1590/s1516-89132010000200013

23. Kunnumakkara $A B$, Anand $P$, Aggarwal $B B$. Curcumin inhibits proliferation, invasion, angiogenesis and metastasis of different cancers through interaction with multiple cell signaling proteins. Cancer Lett. 2008;269(2):199-225. https://doi.org/10.1016/j. canlet.2008.03.009

PMid: 18479807

24. Lin MT, Chang CC, Chen ST, Chang HL, Su JL, Chau YP, et al. Cyr61 expression confers resistance to apoptosis in breast cancer MCF-7 cells by a mechanism of NF-kappaB-dependent XIAP up-regulation. J Biol Chem. 2004;279(23):24015-23. https://doi.org/10.1074/jbc.m402305200

PMid:15044484

25. Ramasamy TS, Ayob AZ, Myint HHL, Thiagarajah S, Amini F. Targeting colorectal cancer stem cells using curcumin and curcumin analogues: Insights into the mechanism of the therapeutic efficacy. Cancer Cell Int. 2015;15(1):96. https://doi. org/10.1186/s12935-015-0241-x

PMid:26457069

26. Patel SS, Acharya A, Ray RS, Agrawal R, Raghuwanshi R, Jain P. Cellular and molecular mechanisms of curcumin in prevention and treatment of disease. Crit Rev Food Sci Nutr. 2020;60(6):887-939. https://doi.org/10.1080/10408398.2018.15 52244

PMid:30632782

27. De Araújo Júnior RF, de Souza TP, Pires JG, Soares LA, de Araújo AA, Petrovick PR, et al. A dry extract of Phyllanthus niruri protects normal cells and induces apoptosis in human liver carcinoma cells. Exp Biol Med (Maywood). 2012;237(11):1281-8. https://doi.org/10.1258/ebm.2012.012130

PMid:23239439

28. Tseng HH, Chen PN, Kuo WH, Wang JW, Chu SC, Hsieh YS. Antimetastatic potentials of phyllanthus urinaria L on A549 and Lewis lung carcinoma cells via repression of matrix-degrading proteases. Integr Cancer Ther. 2012;11(3):267-78. https://doi. org/10.1177/1534735411417128

PMid:22144737

29. Tanvir EM, Hossen MS, Hossain MF, Afroz R, Gan SH, Khalil MI, et al. Antioxidant properties of popular turmeric (Curcuma longa) varieties from Bangladesh. J Food Qual. 2017;2017:8471785. https://doi.org/10.1155/2017/8471785

30. Amalina ND, Suzery M, Cahyono B. Cytotoxic activity of Hyptis pectinata extracts on MCF-7 human breast cancer cells. Indones J Cancer Chemoprev. 2020;11(1):1-6. https://doi.org/10.14499/ indonesianjcanchemoprev11iss1pp1-6

31. Mosmann T. Rapid colorimetric assay for cellular growth and survival: Application to proliferation and cytotoxicity assays. J Immunol Methods. 1983;65(1-2):55-63. https://doi. org/10.1016/0022-1759(83)90303-4 PMid:6606682

32. Ikawati M, Jenie RI, Utomo RY, Amalina ND, Nur Ilmawati GP, Kawaichi $M$, et al. Genistein enhances cytotoxic and antimigratory activities of doxorubicin on $4 \mathrm{~T} 1$ breast cancer cells through cell cycle arrest and ROS generation. J Appl Pharm Sci. 2020;10(10):95-104. https://doi.org/10.7324/japs.2020.1010011

33. Miladiyah I, Yuanita E, Nuryadi S, Jumina J, Haryana SM, Mustofa M. Synergistic effect of 1,3,6-trihydroxy-4,5,7trichloroxanthone in combination with doxorubicin on B-cell lymphoma cells and its mechanism of action through molecular docking. Curr Ther Res - Clin Exp. 2020;92:100576. https://doi. org/10.1016/j.curtheres.2020.100576

PMid:32123546

34. Reynolds CP, Maurer BJ. Evaluating response to antineoplastic drug combinations in tissue culture models. Methods Mol Med. 2005;110(2):173-83. https://doi.org/10.1385/1-59259-869-2:173 PMid:15901935

35. Jenie RI, Amalina ND, IImawati GPN, Utomo RY, Ikawati M, Khumaira A, et al. Cell cycle modulation of $\mathrm{CHO}-\mathrm{K} 1$ cells under genistein treatment correlates with cells senescence, apoptosis and ROS level but in a dose-dependent manner. Adv Pharm Bull. 2019;9(3):453-61. https://doi.org/10.15171/apb.2019.054 PMid:31592434

36. Hacker G. The morphology of apoptosis. Cell Tissue Res. 2000;301(1):5-17.

PMid: 10928277

37. Suzery M, Cahyono B, Amalina ND. Antiproliferative and apoptosis effect of hyptolide from Hyptis pectinata (L.) Poit on human breast cancer cells. J Appl Pharm Sci. 2020;10(02):1-6. https://doi.org/10.7324/japs.2020.102001

38. Fadeel B, Orrenius S. Apoptosis: A basic biological phenomenon with wide-ranging implications in human disease. J Intern Med. 2005;258(6):479-517. https://doi. org/10.1111/j.1365-2796.2005.01570.x

PMid:16313474

39. Liu D, Chen Z. The effect of curcumin on breast cancer cells. J Breast Cancer. 2013;16(2):133-7.

PMid:23843843

40. Butz AM. Cancer stem cells: Cellular plasticity, niche, and its clinical relevance. J Stem Cell Res Ther. 2016;10(6):139-48. https://doi.org/10.4172/2157-7633.1000363

PMid:27891292

41. Huang Z, Wu T, Liu AY, Ouyang G. Differentiation and transdifferentiation potentials of cancer stem cells. Oncotarget. 2015;6(37):39550-63. https://doi.org/10.18632/oncotarget.6098 PMid:26474460

42. Muhar AM, Putra A, Warli SM, Munir D. Hypoxia-mesenchymal stem cells inhibit intra-peritoneal adhesions formation by upregulation of the il-10 expression. Open Access Maced J Med Sci. 2019;7(23):3937-43. https://doi.org/10.3889/ oamjms.2019.713

PMid:32165932

43. Bendas G, Borsig L. Cancer cell adhesion and metastasis: Selectins, integrins, and the inhibitory potential of heparins. Int J Cell Biol. 2012;2012. https://doi.org/10.1155/2012/676731 PMid:22505933

44. Staquicini DI, Rangel R, Guzman-Rojas L, Staquicini FI, Dobroff AS, Tarleton CA, et al. Intracellular targeting of annexin A2 inhibits tumor cell adhesion, migration, and in vivo grafting. Sci Rep. 2017;7(1):1-11. https://doi.org/10.1038/ s41598-017-03470-w

45. Barberán $S$, Cebrià $F$. The role of the EGFR signaling pathway in stem cell differentiation during planarian regeneration and homeostasis. Semin Cell Dev Biol. 2019;87:45-57. https://doi. org/10.1016/j.semcdb.2018.05.011 PMid:29775660

46. Jamaladdin S, Kelly RD, O'Regan L, Dovey OM, Hodson GE, Millard CJ, etal. Histone deacetylase (HDAC) 1 and 2 are essential 
for accurate cell division and the pluripotency of embryonic stem cells. Proc Natl Acad Sci U S A. 2014;111(27):9840-5. https:// doi.org/10.1073/pnas.1321330111

PMid:24958871

47. Massard C, Deutsch E, Soria JC. Tumour stem celltargeted treatment: Elimination or differentiation. Ann Oncol. 2006;17(11):1620-4. https://doi.org/10.1093/annonc/mdl074 PMid:16600978

48. Ayob AZ, Ramasamy TS. Cancer stem cells as key drivers of tumour progression. J Biomed Sci. 2018;25(1):20. https://doi. org/10.1186/s12929-018-0426-4 PMid:29506506

49. Phi LT, Sari IN, Yang YG, Lee SH, Jun N, Kim KS, et al. Cancer stem cells (CSCs) in drug resistance and their therapeutic implications in cancer treatment. Stem Cells Int. 2018;2018:5416923. https://doi.org/10.1155/2018/5416923 PMid:29681949

50. Demain AL, Vaishnav P. Natural products for cancer chemotherapy. Microb Biotechnol. 2011;4(6):687-99. PMid:21375717

51. SaG,Das T.Anticancer effects of curcumin: Cycle oflife and death Cell Div. 2008;3:14. https://doi.org/10.1186/1747-1028-3-14 PMid: 18834508

52. Tomeh MA, Hadianamrei R, Zhao X. A review of curcumin and its derivatives as anticancer agents. Int J Mol Sci. 2019;20(5):1033. https://doi.org/10.3390/ijms20051033

PMid:30818786

53. Kunwar A, Barik A, Mishra B, Rathinasamy K, Pandey R, Priyadarsini KI. Quantitative cellular uptake, localization and cytotoxicity of curcumin in normal and tumor cells. Biochim Biophys Acta. 2008;1780(4):673-9. https://doi.org/10.1016/j. bbagen.2007.11.016

PMid:18178166

54. Zhou Q, Ye M, Lu Y, Zhang H, Chen Q, Huang S, et al. Curcumin improves the tumoricidal effect of mitomycin $\mathrm{C}$ by suppressing ABCG2 expression in stem cell-like breast cancer cells. PLoS One. 2015;10(8):e0136694. https://doi.org/10.1371/journal. pone. 0136694

PMid:26305906
55. Zhou QM, Sun Y, Lu YY, Zhang H, Chen QL, Su SB. Curcumin reduces mitomycin $C$ resistance in breast cancer stem cells by regulating $\mathrm{Bcl}-2$ family-mediated apoptosis. Cancer Cell Int. 2017;17(1):1-13. https://doi.org/10.1186/s12935-017-0453-3 PMid:28959140

56. Putra A, Riwanto I, Putra ST, Wijaya I. Typhonium flagelliforme extract induce apoptosis in breast cancer stem cells by suppressing survivin. J Cancer Res Ther. 2020;16(6):1302-8.

57. Lee SH, Jaganath IB, Wang SM, Sekaran SD. Antimetastatic effects of Phyllanthus on human lung (A549) and breast (MCF-7) cancer cell lines. PLoS One. 2011;6(6):e20994. https:// doi.org/10.1371/journal.pone.0020994 PMid:21698198

58. Chen CY, Lin YS, Chen CH, Chen YJ. Annexin A2-mediated cancer progression and therapeutic resistance in nasopharyngeal carcinoma. J Biomed Sci. 2018;25(1):30. https://doi.org/10.1186/s12929-018-0430-8

PMid:29598816

59. Heddleston JM, Li Z, Lathia JD, Bao S, Hjelmeland AB, Rich JN Hypoxia inducible factors in cancer stem cells. $\mathrm{Br} \mathrm{J}$ Cancer. 2010;102(5):789-95. https://doi.org/10.1038/sj.bjc.6605551 PMid:20104230

60. Abhold EL, Kiang A, Rahimy E, Kuo SZ, Wang-Rodriguez J, Lopez JP, et al. EGFR kinase promotes acquisition of stem cell-like properties: A potential therapeutic target in head and neck squamous cell carcinoma stem cells. PLoS One. 2012;7(2):e32459. https://doi.org/10.1371/journal. pone.0032459

PMid:22384257

61. Saja K, Babu MS, Karunagaran D, Sudhakaran PR. Antiinflammatory effect of curcumin involves downregulation of MMP-9 in blood mononuclear cells. Int Immunopharmacol. 2007;7(13):1659-67. https://doi.org/10.1016/j.intimp.2007.08.018 PMid:17996675

62. Kabakov A, Yakimova A, Matchuk O. Molecular chaperones in cancer stem cells: Determinants of stemness and potential targets for antitumor therapy. Cells. 2020;9(4):892. https://doi. org/10.3390/cells9040892

PMid:32268506

Author Query???

AQ1: We are able to not process this table no 3 . please check and advise

AQ2: Kindly provide suplementary Table header 
suplementary Table 1 ???

\begin{tabular}{|c|c|c|c|c|}
\hline \multirow[t]{2}{*}{ Rank } & \multirow[t]{2}{*}{ Correlation } & Seed vector & Target Vector idebt & Target vector \\
\hline & & description for & For display & Display for \\
\hline 57 & 0.52 & CURCUMIN & GC382441 & CHD4 \\
\hline 58 & 0.52 & CURCUMIN & GC382639 & KHDRBS1 \\
\hline 60 & 0.52 & CURCUMIN & GC415957 & U2AF1 \\
\hline 61 & 0.52 & CURCUMIN & GC397232 & SMARCC1 \\
\hline 62 & 0.52 & CURCUMIN & GC16214 & CPT1C \\
\hline 63 & 0.52 & CURCUMIN & GC32693 & TAF12 \\
\hline 64 & 0.52 & CURCUMIN & GC410576 & RPF2 \\
\hline 65 & 0.52 & CURCUMIN & GC397403 & HDAC1 \\
\hline 66 & 0.52 & CURCUMIN & GC257044 & RBBP4 \\
\hline 67 & 0.52 & CURCUMIN & GC397651 & KHDRBS1 \\
\hline 69 & 0.52 & CURCUMIN & GC255719 & TCF3 \\
\hline 70 & 0.52 & CURCUMIN & GC16168 & PPP1R8 \\
\hline 72 & 0.51 & CURCUMIN & GC56403 & CHEK2 \\
\hline 73 & 0.51 & CURCUMIN & GC184242 & RABEPK \\
\hline 74 & 0.51 & CURCUMIN & GC382464 & SRRM1 \\
\hline 76 & 0.51 & CURCUMIN & GC282748 & C22orf34 \\
\hline 77 & 0.51 & CURCUMIN & GC382380 & TRA2B \\
\hline 79 & 0.51 & CURCUMIN & GC171597 & HNRNPR \\
\hline 80 & 0.51 & CURCUMIN & GC187777 & ATAD3A \\
\hline 82 & 0.51 & CURCUMIN & GC384395 & CCNF \\
\hline 83 & 0.51 & CURCUMIN & GC384141 & ZBTB40 \\
\hline 84 & 0.51 & CURCUMIN & GC264147 & RBBP4 \\
\hline 85 & 0.51 & CURCUMIN & GC393435 & S100PBP \\
\hline 86 & 0.51 & CURCUMIN & GC257220 & ODF2 \\
\hline 87 & 0.51 & CURCUMIN & GC35203 & NFATC2IP \\
\hline 88 & 0.51 & CURCUMIN & GC37811 & SLC25A36 \\
\hline 90 & 0.51 & CURCUMIN & GC85211 & ATAD3B \\
\hline 91 & 0.51 & CURCUMIN & GC421500 & C1orf174 \\
\hline 92 & 0.51 & CURCUMIN & GC396851 & SRSF4 \\
\hline 95 & 0.51 & CURCUMIN & GC383951 & PCNT \\
\hline 96 & 0.51 & CURCUMIN & GC384561 & ZZEF1 \\
\hline 97 & 0.5 & CURCUMIN & GC386207 & SLC19A1 \\
\hline 99 & 0.5 & CURCUMIN & GC270113 & ZNRD1 \\
\hline 100 & 0.5 & CURCUMIN & GC31073 & BTAF1 \\
\hline 102 & 0.5 & CURCUMIN & GC15330 & PNRC2 \\
\hline 105 & 0.5 & CURCUMIN & GC171761 & ATAD3B \\
\hline 106 & 0.5 & CURCUMIN & GC257194 & GRK4 \\
\hline 107 & 0.5 & CURCUMIN & GC102206 & HNRNPA2B1 \\
\hline 108 & 0.5 & CURCUMIN & GC391447 & CCNL1 \\
\hline 109 & 0.5 & CURCUMIN & GC98228 & DCP1A \\
\hline 110 & 0.5 & CURCUMIN & GC397043 & SDHB \\
\hline 112 & 0.5 & CURCUMIN & GC382062 & DDX39B \\
\hline 114 & 0.5 & CURCUMIN & GC391207 & PDSS1 \\
\hline 115 & 0.5 & CURCUMIN & GC408960 & $\mathrm{RCC} 2$ \\
\hline 116 & 0.5 & CURCUMIN & GC392212 & MRTO4 \\
\hline 117 & 0.5 & CURCUMIN & GC96349 & SLC19A1 \\
\hline 1 & -0.63 & CURCUMIN & GC265288 & RASAL2 \\
\hline 2 & -0.59 & CURCUMIN & GC281649 & RASAL2 \\
\hline 3 & -0.59 & CURCUMIN & GC405831 & CLIP4 \\
\hline 4 & -0.58 & CURCUMIN & GC409778 & CLIP4 \\
\hline 5 & -0.57 & CURCUMIN & GC14289 & RFC3 \\
\hline 6 & -0.57 & CURCUMIN & GC9827 & TMCO1 \\
\hline 9 & -0.55 & CURCUMIN & GC10417 & GIGYF2 \\
\hline 10 & -0.55 & CURCUMIN & GC98923 & RASAL2 \\
\hline 11 & -0.55 & CURCUMIN & GC392962 & TMEM245 \\
\hline 12 & -0.54 & CURCUMIN & GC92198 & RASAL2 \\
\hline 13 & -0.54 & CURCUMIN & GC175647 & RASAL2 \\
\hline 15 & -0.54 & CURCUMIN & GC189569 & CLIP4 \\
\hline 16 & -0.54 & CURCUMIN & GC160964 & AHNAK2 \\
\hline 17 & -0.54 & CURCUMIN & GC388269 & EGFR \\
\hline 18 & -0.53 & CURCUMIN & GC54614 & WWC1 \\
\hline 20 & -0.53 & CURCUMIN & GC387675 & EGFR \\
\hline 21 & -0.53 & CURCUMIN & GC67614 & RASAL2 \\
\hline 22 & -0.53 & CURCUMIN & GC395520 & LOC100288911 \\
\hline 23 & -0.53 & CURCUMIN & GC73287 & CLIP4 \\
\hline 24 & -0.53 & CURCUMIN & GC283235 & LOC100288911 \\
\hline 26 & -0.53 & CURCUMIN & GC272846 & CLIP4 \\
\hline 27 & -0.53 & CURCUMIN & GC269551 & RASAL2 \\
\hline 28 & -0.52 & CURCUMIN & GC78555 & C15orf52 \\
\hline 29 & -0.52 & CURCUMIN & GC151105 & WWC1 \\
\hline 30 & -0.52 & CURCUMIN & GC412092 & FAM200B \\
\hline 31 & -0.52 & CURCUMIN & GC249495 & CRIM1 \\
\hline 32 & -0.52 & CURCUMIN & GC162374 & RASAL2 \\
\hline 33 & -0.52 & CURCUMIN & GC279709 & ARHGEF28 \\
\hline 34 & -0.52 & CURCUMIN & GC383037 & EGFR \\
\hline 35 & -0.52 & CURCUMIN & GC246094 & ANXA2 \\
\hline 39 & -0.51 & CURCUMIN & GC85752 & ANXA2 \\
\hline 41 & -0.51 & CURCUMIN & GC255693 & ANXA2P2 \\
\hline 43 & -0.51 & CURCUMIN & GC283236 & LOC100288911 \\
\hline 44 & -0.51 & CURCUMIN & GC15805 & HIF1A \\
\hline 45 & -0.51 & CURCUMIN & GC382912 & EGFR \\
\hline 46 & -0.51 & CURCUMIN & GC183517 & RASAL2 \\
\hline 47 & -0.51 & CURCUMIN & GC419198 & LOC100288911 \\
\hline 49 & -0.51 & CURCUMIN & GC179764 & RASAL2 \\
\hline 50 & -0.51 & CURCUMIN & GC269692 & TMEM245 \\
\hline 52 & -0.51 & CURCUMIN & GC271961 & HIBADH \\
\hline 54 & -0.5 & CURCUMIN & GC397070 & HIF1A \\
\hline
\end{tabular}

suplementary Table I: (Continued)

\begin{tabular}{|c|c|c|c|c|}
\hline \multirow[t]{2}{*}{ Rank } & \multirow[t]{2}{*}{ Correlation } & Seed vector & Target Vector idebt & Target vector \\
\hline & & description for & For display & Display for \\
\hline 55 & -0.5 & CURCUMIN & GC274893 & CRIM1 \\
\hline 56 & -0.5 & CURCUMIN & GC402719 & AHNAK2 \\
\hline 57 & -0.5 & CURCUMIN & GC384111 & THBD \\
\hline 58 & -0.5 & CURCUMIN & GC269658 & TMEM245 \\
\hline 59 & -0.5 & CURCUMIN & GC267119 & CLIP4 \\
\hline 60 & -0.5 & CURCUMIN & GC101811 & null \\
\hline 61 & -0.5 & CURCUMIN & GC269693 & TMEM245 \\
\hline 62 & -0.5 & CURCUMIN & GC249354 & TNFAIP2 \\
\hline 63 & -0.5 & CURCUMIN & GC177839 & null \\
\hline 64 & -0.5 & CURCUMIN & GC28815 & TGM2 \\
\hline 65 & -0.5 & CURCUMIN & GC392961 & TMEM245 \\
\hline 66 & -0.5 & CURCUMIN & GC269694 & TMEM245 \\
\hline 67 & -0.5 & CURCUMIN & GC268109 & ANKRD2 \\
\hline 1 & 0.72 & CURCUMIN & GC16324 & MANEAL \\
\hline 2 & 0.64 & CURCUMIN & GC386657 & HNRNPR \\
\hline 3 & 0.63 & CURCUMIN & GC397562 & RPL11 \\
\hline 5 & 0.62 & CURCUMIN & GC386658 & HNRNPR \\
\hline 6 & 0.6 & CURCUMIN & GC170494 & ATAD3B \\
\hline 7 & 0.6 & CURCUMIN & GC397563 & RPL11 \\
\hline 8 & 0.59 & CURCUMIN & GC15534 & РМРСВ \\
\hline 9 & 0.59 & CURCUMIN & GC385739 & PPP1R8 \\
\hline 10 & 0.59 & CURCUMIN & GC391502 & ATAD3A \\
\hline 11 & 0.59 & CURCUMIN & GC393846 & ATAD3A \\
\hline 13 & 0.57 & CURCUMIN & GC388725 & SRSF10 \\
\hline 14 & 0.57 & CURCUMIN & GC33307 & RBBP4 \\
\hline 16 & 0.57 & CURCUMIN & GC390415 & PNRC2 \\
\hline 17 & 0.57 & CURCUMIN & GC392815 & ATAD3B \\
\hline 18 & 0.57 & CURCUMIN & GC11583 & MMP9 \\
\hline 19 & 0.56 & CURCUMIN & GC30216 & HNRNPR \\
\hline 20 & 0.56 & CURCUMIN & GC164030 & ATAD3A \\
\hline 22 & 0.55 & CURCUMIN & GC265230 & TMEM $39 \mathrm{~B}$ \\
\hline 23 & 0.55 & CURCUMIN & GC386665 & TCP1 \\
\hline 24 & 0.55 & CURCUMIN & GC385792 & SRSF10 \\
\hline 25 & 0.55 & CURCUMIN & GC393018 & YTHDF2 \\
\hline 26 & 0.55 & CURCUMIN & GC396451 & STAG1 \\
\hline 28 & 0.55 & CURCUMIN & GC392055 & $\mathrm{COQ} 3$ \\
\hline 29 & 0.55 & CURCUMIN & GC382442 & CHD4 \\
\hline 30 & 0.55 & CURCUMIN & GC37945 & DFFB \\
\hline 32 & 0.55 & CURCUMIN & GC397652 & KHDRBS1 \\
\hline 33 & 0.55 & CURCUMIN & GC13127 & HNRNPR \\
\hline 34 & 0.54 & CURCUMIN & GC383648 & MDC1 \\
\hline 35 & 0.54 & CURCUMIN & GC14383 & SPI1 \\
\hline 37 & 0.54 & CURCUMIN & GC27389 & SRSF4 \\
\hline 38 & 0.54 & CURCUMIN & GC247512 & RPL11 \\
\hline 39 & 0.54 & CURCUMIN & GC396479 & HSP90AB1 \\
\hline 40 & 0.54 & CURCUMIN & GC413387 & SNHG12 \\
\hline 41 & 0.54 & CURCUMIN & GC48107 & DCP1A \\
\hline 42 & 0.54 & CURCUMIN & GC382534 & SMARCC1 \\
\hline 43 & 0.54 & CURCUMIN & GC384140 & ZBTB40 \\
\hline 45 & 0.53 & CURCUMIN & GC30500 & MTHFD2 \\
\hline 46 & 0.53 & CURCUMIN & GC31808 & SNRNP40 \\
\hline 47 & 0.53 & CURCUMIN & GC413381 & SNHG12 \\
\hline 48 & 0.53 & CURCUMIN & GC386272 & SLC19A1 \\
\hline 49 & 0.53 & CURCUMIN & GC421454 & YARS \\
\hline 50 & 0.53 & CURCUMIN & GC265256 & DAZAP1 \\
\hline 51 & 0.53 & CURCUMIN & GC31222 & AK2 \\
\hline 52 & 0.53 & CURCUMIN & GC394915 & ATAD3B \\
\hline 53 & 0.53 & CURCUMIN & GC382463 & SRRM1 \\
\hline 55 & 0.53 & CURCUMIN & GC383649 & MDC1 \\
\hline 56 & 0.53 & CURCUMIN & GC255478 & HNRNPR \\
\hline
\end{tabular}


AQ2 suplementary Table 2 ???

\begin{tabular}{|c|c|c|c|c|}
\hline \multirow[t]{2}{*}{ Rank } & Correlation & Seed vector & Target Vector idebt & Target vector \\
\hline & & description for & For display & Display for \\
\hline 94 & 0.64 & PHYLLANTHIN & GC411175 & ABHD17B \\
\hline 74 & -0.5 & PHYLLANTHIN & GC400089 & CRYGC \\
\hline 73 & -0.5 & PHYLLANTHIN & GC77299 & KLHL26 \\
\hline 76 & -0.5 & PHYLLANTHIN & GC71505 & SETD6 \\
\hline 59 & -0.51 & PHYLLANTHIN & GC57513 & ACER2 \\
\hline 63 & -0.51 & PHYLLANTHIN & GC13957 & AVPI1 \\
\hline 61 & -0.51 & PHYLLANTHIN & GC382090 & CANX \\
\hline 70 & -0.51 & PHYLLANTHIN & GC89176 & $\mathrm{CDH} 8$ \\
\hline 62 & -0.51 & PHYLLANTHIN & GC96853 & CLTCL1 \\
\hline 69 & -0.51 & PHYLLANTHIN & GC269143 & GNG3 \\
\hline 66 & -0.51 & PHYLLANTHIN & GC18210 & GSTT2B \\
\hline 64 & -0.51 & PHYLLANTHIN & GC12560 & HOXB5 \\
\hline 65 & -0.51 & PHYLLANTHIN & GC100193 & KCNA6 \\
\hline 60 & -0.51 & PHYLLANTHIN & GC63286 & KIAA1257 \\
\hline 57 & -0.51 & PHYLLANTHIN & GC183485 & KIF3B \\
\hline 71 & -0.51 & PHYLLANTHIN & GC253885 & ZNF205 \\
\hline 50 & -0.52 & PHYLLANTHIN & GC388558 & ANXA2 \\
\hline 55 & -0.52 & PHYLLANTHIN & GC382841 & ANXA2 \\
\hline 56 & -0.52 & PHYLLANTHIN & GC387641 & ANXA2 \\
\hline 52 & -0.52 & PHYLLANTHIN & GC100505 & CFHR2 \\
\hline 46 & -0.52 & PHYLLANTHIN & GC74837 & FRG1B \\
\hline 53 & -0.52 & PHYLLANTHIN & GC10662 & MAP3K5 \\
\hline 54 & -0.52 & PHYLLANTHIN & GC39938 & $\mathrm{RHO}$ \\
\hline 51 & -0.52 & PHYLLANTHIN & GC12826 & SLC25A22 \\
\hline 44 & -0.53 & PHYLLANTHIN & GC54897 & DOPEY1 \\
\hline 42 & -0.53 & PHYLLANTHIN & GC12470 & GCA \\
\hline 39 & -0.53 & PHYLLANTHIN & GC89555 & HOXC4 \\
\hline 40 & -0.53 & PHYLLANTHIN & GC14484 & LRRC49 \\
\hline 41 & -0.53 & PHYLLANTHIN & GC17732 & LYVE1 \\
\hline 43 & -0.53 & PHYLLANTHIN & GC17779 & SERPINH1 \\
\hline 34 & -0.54 & PHYLLANTHIN & GC42321 & CPNE8 \\
\hline 30 & -0.54 & PHYLLANTHIN & GC85757 & GRM5 \\
\hline 31 & -0.54 & PHYLLANTHIN & GC67438 & KIAA2013 \\
\hline 37 & -0.54 & PHYLLANTHIN & GC9809 & MYO1E \\
\hline 32 & -0.54 & PHYLLANTHIN & GC418433 & NUDT16 \\
\hline 33 & -0.54 & PHYLLANTHIN & GC14218 & PPP1R14C \\
\hline 35 & -0.54 & PHYLLANTHIN & GC14031 & TEAD1 \\
\hline 24 & -0.55 & PHYLLANTHIN & GC16013 & FAM129B \\
\hline 26 & -0.55 & PHYLLANTHIN & GC78064 & KIAA1432 \\
\hline 28 & -0.55 & PHYLLANTHIN & GC397418 & PKM \\
\hline 22 & -0.56 & PHYLLANTHIN & GC55618 & BRAP \\
\hline 21 & -0.56 & PHYLLANTHIN & GC18216 & CAPN12 \\
\hline 23 & -0.56 & PHYLLANTHIN & GC16244 & RALB \\
\hline 20 & -0.56 & PHYLLANTHIN & GC44018 & STARD13-AS \\
\hline 16 & -0.57 & PHYLLANTHIN & GC91520 & HACE1 \\
\hline 17 & -0.57 & PHYLLANTHIN & GC12073 & SPECC1 \\
\hline 15 & -0.58 & PHYLLANTHIN & GC11826 & $\mathrm{HAO} 1$ \\
\hline 13 & -0.58 & PHYLLANTHIN & GC16297 & IGFBP6 \\
\hline 14 & -0.58 & PHYLLANTHIN & GC16157 & TBK1 \\
\hline 12 & -0.59 & PHYLLANTHIN & GC101167 & KRT83 \\
\hline 195 & 0.6 & PHYLLANTHIN & GC181232 & CD1D \\
\hline 200 & 0.6 & PHYLLANTHIN & GC258803 & CHRNA3 \\
\hline 197 & 0.6 & PHYLLANTHIN & GC390513 & EVL \\
\hline 194 & 0.6 & PHYLLANTHIN & GC387446 & ITK \\
\hline 196 & 0.6 & PHYLLANTHIN & GC389990 & PMS2P1 \\
\hline 184 & 0.61 & PHYLLANTHIN & GC265275 & ATAD2 \\
\hline 185 & 0.61 & PHYLLANTHIN & GC260950 & AZI1 \\
\hline 180 & 0.61 & PHYLLANTHIN & GC401477 & BPTF \\
\hline 176 & 0.61 & PHYLLANTHIN & GC422381 & CBX2 \\
\hline 168 & 0.61 & PHYLLANTHIN & GC28493 & CBX3 \\
\hline 175 & 0.61 & PHYLLANTHIN & GC37934 & CD1A \\
\hline 174 & 0.61 & PHYLLANTHIN & GC180872 & CHD1 \\
\hline 186 & 0.61 & PHYLLANTHIN & GC257084 & CHRNA3 \\
\hline 192 & 0.61 & PHYLLANTHIN & GC183459 & CYTH1 \\
\hline 178 & 0.61 & PHYLLANTHIN & GC288491 & ESCO2 \\
\hline 173 & 0.61 & PHYLLANTHIN & GC273466 & FYB \\
\hline 162 & 0.61 & PHYLLANTHIN & GC81244 & FYB \\
\hline 170 & 0.61 & PHYLLANTHIN & GC383807 & JARID2 \\
\hline 169 & 0.61 & PHYLLANTHIN & GC177074 & JARID2 \\
\hline 191 & 0.61 & PHYLLANTHIN & GC154719 & LOC728485 \\
\hline 160 & 0.61 & PHYLLANTHIN & GC406275 & LPAR6 \\
\hline 165 & 0.61 & PHYLLANTHIN & GC26995 & ME2 \\
\hline 179 & 0.61 & PHYLLANTHIN & GC401644 & PIKFYVE \\
\hline 166 & 0.61 & PHYLLANTHIN & GC34575 & PMS2P1 \\
\hline 190 & 0.61 & PHYLLANTHIN & GC152451 & RASD1 \\
\hline 161 & 0.61 & PHYLLANTHIN & GC166154 & SEPT6 \\
\hline 159 & 0.61 & PHYLLANTHIN & GC386647 & SLIT1 \\
\hline 187 & 0.61 & PHYLLANTHIN & GC403069 & SMA4 \\
\hline 181 & 0.61 & PHYLLANTHIN & GC398843 & STAU2 \\
\hline 182 & 0.61 & PHYLLANTHIN & GC275611 & TBCD \\
\hline 189 & 0.61 & PHYLLANTHIN & GC383847 & TFDP2 \\
\hline 183 & 0.61 & PHYLLANTHIN & GC37747 & TFDP2 \\
\hline 164 & 0.61 & PHYLLANTHIN & GC410258 & TFDP2 \\
\hline 157 & 0.61 & PHYLLANTHIN & GC167809 & TNRC6C \\
\hline 163 & 0.61 & PHYLLANTHIN & GC189678 & TREML2 \\
\hline 158 & 0.61 & PHYLLANTHIN & GC166321 & ZNF273 \\
\hline 11 & -0.61 & PHYLLANTHIN & GC51594 & CAAP1 \\
\hline 152 & 0.62 & PHYLLANTHIN & GC188756 & ADAM22 \\
\hline 143 & 0.62 & PHYLLANTHIN & GC386719 & ADAM22 \\
\hline 154 & 0.62 & PHYLLANTHIN & GC274494 & ANXA2R \\
\hline
\end{tabular}

suplementary Table 2: Continued

\begin{tabular}{|c|c|c|c|c|}
\hline \multirow[t]{2}{*}{ Rank } & \multirow[t]{2}{*}{ Correlation } & \multirow{2}{*}{$\begin{array}{l}\text { Seed vector } \\
\text { description for }\end{array}$} & \multirow{2}{*}{$\begin{array}{l}\text { Target Vector idebt } \\
\text { For display }\end{array}$} & \multirow{2}{*}{$\begin{array}{l}\text { Target vector } \\
\text { Display for }\end{array}$} \\
\hline & & & & \\
\hline 140 & 0.62 & PHYLLANTHIN & GC273918 & ATG4D \\
\hline 133 & 0.62 & PHYLLANTHIN & GC164346 & DKFZP586I1420 \\
\hline 135 & 0.62 & PHYLLANTHIN & GC191274 & DTX2P1-UPK3BP1-PMS2P11 \\
\hline 151 & 0.62 & PHYLLANTHIN & GC177885 & ITK \\
\hline 131 & 0.62 & PHYLLANTHIN & GC420450 & LRRC70 \\
\hline 149 & 0.62 & PHYLLANTHIN & GC67065 & MOB1B \\
\hline 138 & 0.62 & PHYLLANTHIN & GC261095 & MTMR4 \\
\hline 145 & 0.62 & PHYLLANTHIN & GC177974 & PMS2P1 \\
\hline
\end{tabular}

$155 \quad 0.62$

$\begin{array}{ll}147 & 0.62\end{array}$

$132 \quad 0.62$

$\begin{array}{ll}46 & 0.62 \\ -134 & 0.62\end{array}$

$34 \quad 0.62$

$150 \quad 0.62$

$\begin{array}{ll}116 & 0.63 \\ 128 & 0.63\end{array}$

$22 \quad 0.63$

$\begin{array}{ll}23 & 0.63 \\ 118 & 0.63\end{array}$

1180.63

210.63

290.63

$24 \quad 0.63$

$\begin{array}{ll}125 & 0.63 \\ 120 & 0.63\end{array}$

$\begin{array}{ll}119 & 0.63\end{array}$

$14 \quad 0.63$

$\begin{array}{ll}126 & 0.63\end{array}$

$113 \quad 0.63$

$90 \quad 0.64$

$83 \quad 0.64$

$\begin{array}{ll}89 & 0.64 \\ -110 & 0.64\end{array}$

$\begin{array}{ll}110 & 0.64\end{array}$

$105 \quad 0.64$

$\begin{array}{ll}111 & 0.64 \\ 107 & 0.64\end{array}$

$82 \quad 0.64$

$84 \quad 0.64$

$109 \quad 0.64$

$96 \quad 0.64$

$98 \quad 0.64$

$104 \quad 0.64$

$92 \quad 0.64$

$86 \quad 0.64$

$99 \quad 0.64$

10.64

0.64

50.64

$\begin{array}{ll}80 & 0.64 \\ 106 & 0.64\end{array}$

010.64

$8 \quad-0.64$

$\begin{array}{ll}-0.64 \\ 70 & 0.65\end{array}$

0.65

$\begin{array}{ll}68 & 0.65 \\ 68 & 0.65\end{array}$

$\begin{array}{ll}6 & 0.65 \\ -67 & -1\end{array}$

$7 \quad 0.65$

$\begin{array}{ll}73 & 0.65 \\ 66 & 0.65\end{array}$

$\begin{array}{ll}66 & 0.65 \\ 72 & 0.65\end{array}$

$\begin{array}{ll}7 & 0.65 \\ 7 & 0.65\end{array}$

$\begin{array}{ll}76 & 0.65\end{array}$

$74 \quad 0.65$

80.65

640.65

$\begin{array}{ll}5 & -0.65 \\ 56 & 0.66\end{array}$

$\begin{array}{ll}57 & 0.66\end{array}$

$51 \quad 0.66$

$46 \quad 0.66$

0.66

$\begin{array}{ll}49 & 0.66 \\ 50 & 0.66\end{array}$

$\begin{array}{ll}50 & 0.66 \\ 52 & 0.66\end{array}$

$59 \quad 0.66$

$48 \quad 0.66$

60
4466

$\begin{array}{ll}44 & 0.67 \\ 1 & 0.67\end{array}$

$\begin{array}{ll}42 & 0.67\end{array}$

$\begin{array}{ll}48 & 0.67 \\ 38 & 0.67\end{array}$

$\begin{array}{ll}38 & 0.67\end{array}$

$\begin{array}{ll}36 & 0.68 \\ 35 & 0.68\end{array}$

$31 \quad 0.68$

$37 \quad 0.68$

0.68

\begin{tabular}{ll}
34 & 0.68 \\
\hline & 0.68
\end{tabular}

\begin{tabular}{ll}
28 & 0.68 \\
\hline
\end{tabular}
HYLLANTHIN GC32017

\begin{tabular}{lll} 
PHYLLANTHIN & GC410867 & RBP1R16 \\
\hline & RBM3
\end{tabular}

PHYLLANTHIN GC259281 SEPT6

PHYLLANTHIN GC100902 SMA5

PHYLLANTHIN GC383467 TNFAIP3

PHYLLANTHIN GC30781 $\quad$ YPEL1

PHYLLANTHIN GC83241 CCDC69

PHYLLANTHIN GC81436 GNA13

PHYLLANTHIN GC250372 JARID2

$\begin{array}{lll}\text { PHYLLANTHIN } & \text { GC54687 } & \text { KIAA0922 } \\ \text { PHYLINTHIN } & \text { GC30354 } & \text { KIAA0922 }\end{array}$

PHYLLANTHIN GC415872 MED12L

PHYLLANTHIN GC409739 PAG1

PHYLLANTHIN GC77144 PAG1

PHYLLANTHIN GC402221 PAXIP1

PHYLLANTHIN GC253139 RAD51C

PHYLLANTHIN GC65039 ST8SIA4

PHYLLANTHIN GC409353 USP44

PHYLLANTHIN GC387880 YME1L1

PHYLLANTHIN GC36980 ZNF43

PHYLLANTHIN GC385040 ADAM22

PHYLLANTHIN GC426010 ADAM22

PHYLLANTHIN GC392913 CECR6

PHYLLANTHIN GC383438 GYTH1

PHYLLANTHIN GC160896 GNA13

PHYLLANTHIN GC183619 JARID2

PHYLLANTHIN GC413619 LOC100505555

PHYLLANTHIN GC259441 MTMR4

PHYLLANTHIN GC388787 NEU3

PHYLLANTHIN GC176422 PAG1

PHYLLANTHIN GC272411 $\quad$ PAG1

$\begin{array}{lll}\text { PHYLLANTHIN } & \text { GC272411 } & \text { PAG1 } \\ \text { PC255705 } & \text { PECAM1 }\end{array}$

PHYLLANTHIN GC264365 PLEKHO1

PHYLLANTHIN GC252616 PPM1E

PHYLLANTHIN GC168689 SEPT6

PHYLLANTHIN GC290826 SLC8A1

PHYLLANTHIN GC388591 SMA5

PHYLLANTHIN GC186043 STAU2

PHYLLANTHIN GC81700 TRAT1

PHYLLANTHIN GC403774 YPEL1

PHYLLANTHIN GC185652 YPEL1

PHYLLANTHIN GC16525 $\quad$ SKP1

$\begin{array}{lll}\text { PHYLLANTHIN } & \text { GC16842 } & \text { SPATS2L } \\ \text { PHYLLANTHIN } & \text { GC406751 } & \text { ABHD17B }\end{array}$

PHYLLANTHIN GC254784

PHYLANTHIN GC395492

PHYLLANTHIN GC388190 $\quad$ CHRNA3

$\begin{array}{lll}\text { PHYLLANTHIN } & \text { GC388190 } & \text { CHRNA } \\ \text { PHYLANTHIN } & \text { GC186950 } & \text { EVL }\end{array}$

$\begin{array}{lll}\text { PHYLLANTHIN } & \text { GC186950 } & \text { EVL } \\ \text { PHYLLANTHIN } & \text { GC383473 } & \text { KIAA0195 }\end{array}$

PHYLLANTHIN GC37712 MGA

PHYLLANTHIN GC17785 NT5C3B

PHYLLANTHIN GC273818 PAG1

PHYLLANTHIN GC173253 PHKA1

PHYLLANTHIN GC388613 SLC7A1

PHYLLANTHIN GC271015 USP44

PHYLLANTHIN GC39325 ZNF85

PHYLLANTHIN GC18789 RND3

PHYLLANTHIN GC402418 ADAM22

PHYLLANTHIN GC251191 ADRBK2

PHYLLANTHIN GC391646 C17orf80

PHYLLANTHIN GC90396 CYTH1

PHYLLANTHIN GC148113 PMS2L2

PHYLLANTHIN GC33254 PRKCH

PHYLLANTHIN GC89979 PRKCH

PHYLLANTHIN GC31918 RAD51C

PHYLLANTHIN GC47197 TFDP2

PHYLLANTHIN GC249190 TNFAIP3

PHYLLANTHIN GC407968 TNRC6C

PHYLLANTHIN GC411027 ANXA2R

PHYLLANTHIN GC189655 CCDC102B

PHYLLANTHIN GC249516 CYTH1

$\begin{array}{lll}\text { PHYLLANTHIN } & \text { GC409806 } & \text { PAG1 } \\ \text { PHYLLANTHIN } & \text { GC260186 } & \text { PAXIP1 }\end{array}$

$\begin{array}{lll}\text { PHYLLANTHIN } & \text { GC260186 } & \text { PAXIP1 } \\ \text { PHYLLANTHIN } & \text { GC37018 } & \text { CHRNA3 }\end{array}$

PHYLLANTHIN GC63257 EVL

PHYLLANTHIN GC409544 GNA13

PHYLLANTHIN GC161814 PAG1

PHYLLANTHIN GC73834 PAG1

PHYLLANTHIN GC35292 PMS2P1

$\begin{array}{lll}\text { PHYLLANTHIN } & \text { GC85849 } & \text { PMS2P } \\ & & \end{array}$
PHYLLANTHIN GC249191 TNFAIP3 
suplementary Table 2: Continued

\begin{tabular}{|c|c|c|c|c|}
\hline \multirow[t]{2}{*}{ Rank } & \multirow[t]{2}{*}{ Correlation } & \multirow{2}{*}{$\begin{array}{l}\text { Seed vector } \\
\text { description for }\end{array}$} & \multirow{2}{*}{$\begin{array}{l}\text { Target Vector idebt } \\
\text { For display }\end{array}$} & \multirow{2}{*}{$\begin{array}{l}\text { Target vector } \\
\text { Display for }\end{array}$} \\
\hline & & & & \\
\hline 32 & 0.68 & PHYLLANTHIN & GC386035 & YME1L1 \\
\hline 18 & 0.69 & PHYLLANTHIN & GC17987 & CD1C \\
\hline 21 & 0.69 & PHYLLANTHIN & GC16214 & CPT1C \\
\hline 19 & 0.69 & PHYLLANTHIN & GC383806 & JARID2 \\
\hline 23 & 0.69 & PHYLLANTHIN & GC86218 & KIAA0195 \\
\hline 25 & 0.69 & PHYLLANTHIN & GC164007 & MTMR4 \\
\hline 27 & 0.69 & PHYLLANTHIN & GC426209 & SLC8A1 \\
\hline 2 & -0.69 & PHYLLANTHIN & GC10700 & FLJ41649 \\
\hline 14 & 0.7 & PHYLLANTHIN & GC271745 & GNA13 \\
\hline 17 & 0.7 & PHYLLANTHIN & GC163365 & LINC00340 \\
\hline 16 & 0.7 & PHYLLANTHIN & GC387664 & YME1L1 \\
\hline 13 & 0.71 & PHYLLANTHIN & GC399220 & PRKCH \\
\hline 10 & 0.72 & PHYLLANTHIN & GC290660 & LOC100130476 \\
\hline 8 & 0.73 & PHYLLANTHIN & GC187551 & C17orf80 \\
\hline 7 & 0.73 & PHYLLANTHIN & GC172216 & ZNF577 \\
\hline 5 & 0.74 & PHYLLANTHIN & GC186260 & KIAA0195 \\
\hline 6 & 0.74 & PHYLLANTHIN & GC151093 & KIAA0825 \\
\hline 4 & 0.75 & PHYLLANTHIN & GC16782 & TBL3 \\
\hline 2 & 0.76 & PHYLLANTHIN & GC254783 & ADAM22 \\
\hline 3 & 0.76 & PHYLLANTHIN & GC411749 & PAG1 \\
\hline
\end{tabular}

Supplementary Table 4: A number of 22 mRNA that were related by curcumin and phyllanthin and were related to BBCSCs

\begin{tabular}{|c|c|c|c|c|}
\hline S. No & $\begin{array}{l}\text { Pearson correlation } \\
\text { coefficient }\end{array}$ & $\begin{array}{l}\text { Target } \\
\text { vector ID }\end{array}$ & $\begin{array}{l}\text { Gene } \\
\text { Symbol }\end{array}$ & Gene name \\
\hline 1 & 0.69 & GC383806 & JARID2 & $\begin{array}{l}\text { Jumonji And AT-Rich Interaction } \\
\text { Domain Containing } 2\end{array}$ \\
\hline 2 & 0.65 & GC271015 & USP44 & $\begin{array}{l}\text { Ubiquitin Carbocyl-terminal } \\
\text { hydrolase } 44\end{array}$ \\
\hline 3 & 0.64 & GC249191 & TNFAIP3 & TNF alpha induced protein 3 \\
\hline 4 & 0.61 & GC28493 & CBX3 & Chromobox 3 \\
\hline 5 & 0.61 & GC386647 & SLIT1 & Slit Guidance Ligand 1 \\
\hline 6 & 0.6 & GC170494 & ATAD3B & $\begin{array}{l}\text { ATPase Family AAA Domain } \\
\text { Containing } 3 \mathrm{~B}\end{array}$ \\
\hline 7 & 0.59 & GC393846 & ATAD3A & $\begin{array}{l}\text { ATPase Family AAA Domain } \\
\text { Containing } 3 \mathrm{~A}\end{array}$ \\
\hline 8 & 0.57 & GC11583 & MMP9 & Matrix Metallopeptidase 9 \\
\hline 9 & 0.55 & GC382442 & $\mathrm{CHD} 4$ & $\begin{array}{l}\text { Chromodomain Helicase DNA } \\
\text { Binding Protein } 4\end{array}$ \\
\hline 10 & 0.55 & GC393018 & YTHDF2 & $\begin{array}{l}\text { YTH N6-Methyladenosine RNA } \\
\text { Binding Protein } 2\end{array}$ \\
\hline 11 & 0.54 & GC396479 & HSP90AB1 & $\begin{array}{l}\text { Heat Shock Protein } 90 \text { Alpha } \\
\text { Family Class B Member } 1\end{array}$ \\
\hline 12 & 0.52 & GC397403 & HDAC1 & Histone Deacetylase 1 \\
\hline 13 & 0.52 & GC255719 & TCF3 & Transcription Factor 3 \\
\hline 14 & 0.52 & GC16214 & CPT1C & Carnitine Palmitoyltransferase $1 \mathrm{C}$ \\
\hline 15 & 0.51 & GC15805 & HIF1A & $\begin{array}{l}\text { Hypoxia Inducible Factor } 1 \\
\text { Subunit Alpha }\end{array}$ \\
\hline 16 & -0.5 & GC28815 & TGM2 & Transglutaminase 2 \\
\hline 17 & -0.52 & GC246094 & ANXA2 & Annexin A2 \\
\hline 18 & -0.52 & GC10662 & MAP3K5 & $\begin{array}{l}\text { Mitogen-Activated Protein Kinase } \\
\text { Kinase Kinase } 5\end{array}$ \\
\hline 19 & -0.52 & GC387675 & EGFR & Epidermal Growth Factor Receptor \\
\hline 20 & -0.54 & GC14031 & TEAD1 & TEA Domain Transcription Factor 1 \\
\hline 21 & -0.55 & GC397418 & PKM & Pyruvate Kinase M1/2 \\
\hline 22 & -0.58 & GC16157 & TBK1 & TANK Binding Kinase 1 \\
\hline
\end{tabular}

Supplementary Table 5: Gene ontology of the 22 potential

\begin{tabular}{|c|c|c|}
\hline Term & $p$ value & Genes \\
\hline $\begin{array}{l}\text { Biological process } \\
\text { GO: 0000122 negative } \\
\text { regulation of transcription } \\
\text { from RNA polymerase II } \\
\text { promoter }\end{array}$ & 0.05878410987680528 & $\begin{array}{l}\text { HDAC1, JARID2, } \\
\text { TCF3, CHD4 }\end{array}$ \\
\hline $\begin{array}{l}\text { GO: } \\
\text { 0006351 transcription, } \\
\text { DNA-templated }\end{array}$ & 0.08869262932347735 & $\begin{array}{l}\text { HIF1A, HDAC1, JARID2, } \\
\text { CBX3, TCF3, CHD4 }\end{array}$ \\
\hline $\begin{array}{l}\text { GO: 0045892 negative } \\
\text { regulation of transcription, } \\
\text { DNA-templated }\end{array}$ & 0.12784550606541756 & $\begin{array}{l}\text { HDAC1, } \\
\text { JARID2, CBX3 }\end{array}$ \\
\hline $\begin{array}{l}\text { GO: } 0045893 \sim \text { positive } \\
\text { regulation of transcription, } \\
\text { DNA-templated }\end{array}$ & 0.1345965033431493 & $\begin{array}{l}\text { HIF1A, } \\
\text { HDAC1, TCF3 }\end{array}$ \\
\hline $\begin{array}{l}\text { GO: 0006355 regulation } \\
\text { of transcription, } \\
\text { DNA-templated }\end{array}$ & 0.2893336322416595 & $\begin{array}{l}\text { HIF1A, HDAC1, } \\
\text { TCF3, CHD4 }\end{array}$ \\
\hline $\begin{array}{l}\text { GO: } 0004672 \sim \text { protein } \\
\text { kinase activity }\end{array}$ & 0.07263251481178587 & $\begin{array}{l}\text { EGFR, } \\
\text { MAP3K5, TBK1 }\end{array}$ \\
\hline $\begin{array}{l}\text { GO: } 0098641 \sim \text { cadherin } \\
\text { binding involved in } \\
\text { cell-cell adhesion }\end{array}$ & 0.00530635145361415 & $\begin{array}{l}\text { HSP90AB1, } \\
\text { PKM, EGFR, ANXA2 }\end{array}$ \\
\hline $\begin{array}{l}\text { GO: 0005913 cell-cell } \\
\text { adherens junction }\end{array}$ & 0.0057898661163517506 & $\begin{array}{l}\text { HSP90AB1, PKM, } \\
\text { EGFR, ANXA2 }\end{array}$ \\
\hline $\begin{array}{l}\text { GO: } \\
\text { 0016323 basolateral } \\
\text { plasma membrane }\end{array}$ & 0.01801155022396305 & $\begin{array}{l}\text { HSP9OAB1, } \\
\text { EGFR, ANXA2 }\end{array}$ \\
\hline $\begin{array}{l}\text { GO: 0098609 cell-cell } \\
\text { adhesion }\end{array}$ & 0.04454764908303356 & $\begin{array}{l}\text { HSP90AB1, } \\
\text { PKM, ANXA2 }\end{array}$ \\
\hline $\begin{array}{l}\text { GO: 0044822 poly[A] } \\
\text { RNA binding }\end{array}$ & 0.16227798926506184 & $\begin{array}{l}\text { HSP90AB1, PKM, YTHDF2, } \\
\text { ANXA2 }\end{array}$ \\
\hline $\begin{array}{l}\text { GO: } 0001934 \sim \text { positive } \\
\text { regulation of protein }\end{array}$ & 0.010848600290442318 & $\begin{array}{l}\text { EGFR, } \\
\text { MMP9, ANXA2 }\end{array}$ \\
\hline
\end{tabular}

phosphorylation

Cellular component

0.08871697106273643

HSP90AB1, HIF1A, HDAC1, JARID2, TEAD1, TCF3, CHD4 HSP90AB1, HIF1A, HDAC1, JARID2, TEAD1, TCF3, CHD4 GO:

0.08871697106273643

O: 0054 nucleoplasm

chromatin

GO: 0043234 protein

complex

GO: 0016020 membrane

GO: 0005886 plasma

membrane

$\mathrm{GO}$

0005615 extracellular

space

GO: 0016021 integral

component of membrane

GO: 0009986 cell

surface

Molecular function

GO: 0008270 zinc ion

binding

GO: 0003677 DNA

binding

GO:

0003700 transcription

factor activity,

sequence-specific DNA

binding

GO:

0008134 transcription

factor binding

GO: 0005524 ATP

binding

GO: 0042826 histone

deacetylase binding

polymerase II core

promoter proximal region

sequence-specific DNA

binding
$0.0205301891902419 \quad$ HDAC1,

0.08074688825784038 HDAC1

TCF3, CHD4

HSP90AB1, EGFR

CHD4, ANXA2

PKM, EGFR,

TGM2, ANXA2

SLIT1, ANXA2

0.9915053828035031 CPT1C,

EGFR, ATAD3A

HSP90AB1,

EGFR, ANXA2

0.17459658423852453

MMP9, TNFAIP3,

CHD4, USP44

TEAD1, TNFAIP3

TCF3, CHD4

$\begin{array}{ll}0.11416783095336286 & \text { HIF1A, HDAC1 } \\ \text { TEAD1, TCF3 }\end{array}$

$0.0480050925831412 \quad$ HIF1A

HDAC1, TCF3

2.63E-04

HSP90AB1, PKM, EGFR,

MAP3K5, ATAD3A, ATAD3B

TBK1, TGM2, CHD4

0.007044468809860209 HSP9OAB1

HIF1A, HDAC1

HDAC1, TEAD1

TCF3, CHD4 therapeutic target genes

GO: 0000978 RNA 